Van Wilgenburg, S. L., K. A. Hobson, K. J. Kardynal, and E. M. Beck. 2018. Temporal changes in avian abundance in aspen-dominated boreal mixedwood forests of central Saskatchewan, Canada. Avian Conservation and Ecology 13(1):3. https://doi.org/10.5751/ACE-01145-130103 Copyright $(C) 2018$ by the author(s). Published here under license by the Resilience Alliance.

Research Paper

\title{
Temporal changes in avian abundance in aspen-dominated boreal mixedwood forests of central Saskatchewan, Canada
}

\author{
Steven L. Van Wilgenburg ${ }^{1}$, Keith A. Hobson ${ }^{2}$, Kevin J. Kardynal ${ }^{2}$ and Elizabeth M. Beck ${ }^{l}$ \\ ${ }^{1}$ Environment \& Climate Change Canada, Canadian Wildlife Service, ${ }^{2}$ Environment \& Climate Change Canada, Science and \\ Technology Branch
}

\begin{abstract}
The boreal forest provides important breeding habitat for many migratory songbirds; however, changes in disturbance regimes have led to concern for populations breeding there. Monitoring data to track changes in boreal forest bird populations are scarce. Therefore, we repeated surveys at historic research sites in aspen-dominated boreal mixedwood forest in central Saskatchewan, Canada, to test for changes in abundance in different forest age classes. We used GIS analyses and habitat data to test whether observed changes in abundance were correlated with within-stand changes in habitat over approximately 20 years. Eight of the ten species examined showed evidence for change in abundance. Trends from our study showed little correlation with regional trends from the North American Breeding Bird Survey (BBS) and generally displayed greater magnitude and precision. Species associated with closedcanopy forests declined more rapidly than suggested by BBS surveys, whereas species associated with disturbance generally had opposite trends to the BBS. Decreased abundance of species such as Swainson's Thrush (Catharus ustulatus) and Yellow-rumped Warbler (Setophaga coronata) correlated with loss of forest cover from fire or harvesting. Conversely, changes in the abundance of species associated with early successional forest and canopy gaps were primarily correlated with within-stand disturbances (e.g., Magnolia Warbler [Setophaga magnolia]) and changes in the proportion of the stands composed of conifers (e.g., White-throated Sparrow [Zonotrichia albicollis]). We suggest repeating historic surveys and comparing trends with other monitoring programs to provide a weight-of-evidence approach to assess overall support for changes in species' status for regions where data are sparse. Our results are consistent with previous studies that predict that changes in the forest age-class distribution could alter boreal forest bird abundance and community composition. Long-term conservation plans should integrate projected land-use and climate effects on boreal forest bird populations.
\end{abstract}

\section{Variations temporelles de l'abondance aviaire en forêt mixte boréale dominée par le peuplier dans le centre de la Saskatchewan, Canada}

RÉSUMÉ. La forêt boréale compte d'importants milieux de nidification pour de nombreux passereaux migrateurs. Toutefois, en raison des changements advenus dans les régimes de perturbation, les populations qui y nichent soulèvent des préoccupations. Les suivis mis sur place pour détecter les variations de populations d'oiseaux forestiers boréaux sont rares. Nous avons donc refait des relevés à des sites de recherche historiques en forêt mixte boréale dominée par le peuplier dans le centre de la Saskatchewan, Canada, afin de tester si l'abondance avait changé selon les différentes classes d'âge des forêts. Au moyen d'analyses SIG et de données d'habitat, nous avons testé si les variations observées dans l'abondance étaient corrélées avec les changements d'habitat à l'échelle des peuplements sur une période d'environ 20 ans. Des indices de variation de l'abondance ont été obtenus pour huit des dix espèces examinées. Les tendances tirées de notre étude ont montré peu de corrélation avec les tendances régionales observées dans le cadre du Relevé des oiseaux nicheurs d'Amérique du Nord (BBS), et révélaient généralement une ampleur et une précision plus grandes. Les espèces associées avec les forêts à la voûte fermée ont diminué plus rapidement que ce qu'indiquaient les relevés BBS, tandis que les espèces associées avec les perturbations montraient généralement des tendances opposées à celles du BBS. La baisse d'effectifs d'espèces comme la Grive à dos olive (Catharus ustulatus) et la Paruline à croupion jaune (Setophaga coronata) était corrélée à la perte de couvert forestier imputable au feu ou à la récolte forestière. À l'opposé, la variation de l'abondance d'espèces associées aux forêts de début de succession et aux trouées forestières était surtout corrélée avec les perturbations à l'échelle du peuplement (p. ex. Paruline à tête cendrée [Setophaga magnolia]) et les changements de proportion des peuplements de conifères (p. ex. Bruant à gorge blanche [Zonotrichia albicollis]). Nous proposons de répéter des relevés historiques et de comparer les tendances avec celles d'autres programmes de suivi pour obtenir une approche fondée sur le poids de la preuve afin d'évaluer si l'hypothèse de changements de statut des espèces dans les régions où les données sont rares est globalement appuyée. Nos résultats concordent avec ceux d'études antérieures qui prévoient que le changement des classes d'âge des forêts pourrait modifier l'abondance des oiseaux forestiers boréaux et la composition des communautés. Les plans de conservation à long terme devraient intégrer les effets projetés de l'utilisation du sol et du climat sur les populations d'oiseaux forestiers boréaux.

Key Words: BBS; boreal forest; disturbance; mixedwood forest; point-count; population trend; revisit; Saskatchewan

Address of Correspondent: Steven L. Van Wilgenburg, Environment \& Climate Change Canada, 115- Perimeter Road, Saskatoon, SK Canada S7N 0X4, Steven.vanwilgenburg@Canada.ca 


\section{INTRODUCTION}

The boreal forest contributes substantially to the production of migratory songbird populations in North America (Wells 2011). At least 186 bird species regularly breed in the boreal forest, with an estimated 1-3 billion landbirds breeding in boreal regions of Canada, representing up to $60 \%$ of all landbirds in Canada (Blancher 2003). However, the boreal forest has experienced a dramatic increase in industrial resource extraction in recent decades and is particularly sensitive to projected climatic change (e.g., Hobson et al. 2002a, Schmiegelow and Mönkkönen 2002, Calvert et al. 2013, Stralberg et al. 2015). It is poorly understood how such changes have and will affect migratory birds because there is a paucity of reliable information about status and trends to inform effective conservation and management for boreal species.

The North American Breeding Bird Survey (BBS; https://www. pwrc.usgs.gov/bbs/) has been successfully used to monitor landbirds throughout much of the continent but currently does not provide adequate coverage for boreal forest birds (Machtans et al. 2014, Van Wilgenburg et al. 2015). Owing, in part, to the inadequate BBS coverage in the boreal forest, at least 66 species of landbird are inadequately monitored (Dunn et al. 2005). Additionally, population trajectories of boreal songbirds in northern regions cannot be inferred from data derived from southern regions (Machtans et al. 2014). In boreal Saskatchewan for example, only five BBS routes have ever been run north of agriculturally affected lands (the boreal transition zone) compared to 19 run within the transition zone. Thus, the majority of BBS routes fall within a region where $>75 \%$ of the land has been converted to agriculture (Hobson et al. 2002a) and where those boreal routes that have been surveyed have only been run for five years on average (range: 3-9 years). Recent analyses also highlight biases in roadside sampling with respect to spatial coverage (Matsuoka et al. 2011), habitat representation (Matsuoka et al. 2011), and representation of disturbance rates (Betts et al. 2007, Van Wilgenburg et al. 2015). For example, Matsuoka et al. (2011) found that $62 \%$ of boreal ecozones in Canada were undersampled by roadside surveys. Thus, nonrepresentative sampling may result in inaccurate trend estimates (Betts et al. 2007, Machtans et al. 2014, Van Wilgenburg et al. 2015). Given the current lack of adequate boreal monitoring data and their importance in species assessment and conservation (Machtans et al. 2014, Hudson et al. 2017), other data are needed to evaluate changes in species status and trends (Handel and Sauer 2017)

One approach to rapidly assess population change is to resurvey historic research sites (Kirk et al. 1997, Holmes and Sherry 2001, Machtans et al. 2007). Local surveys and revisits to historic study areas have previously been used to provide external validation of reported trends (Machtans et al. 2014), test hypotheses for the causes of trends (Holmes and Sherry 2001), and examine whether continent-wide declines reported from Christmas Bird Count (Butcher et al. 1990) data reflect broad-scale vs. local declines on the breeding grounds (Machtans et al. 2007). More recently, results from multiple monitoring programs across Ontario were integrated to provide broader insight and certainty around changes in species status and thereby address limitations and biases associated with individual monitoring programs (Blancher et al. 2009). Blancher et al. (2009) included off-road point-count data from the Ontario Breeding Bird Atlas, which was the primary source of trend data for $90 \%$ of species in the boreal shield (Bird Conservation Region [BCR] 8), highlighting the potential utility of local studies employing repeat visits to historic survey locations.

Population trajectories of forest birds can be driven by numerous natural and anthropogenic causes. Successional changes within forest stands have the potential to obscure larger scale patterns of population change and impede identification of potential mechanisms contributing to these trends (Holmes and Sherry 2001). A key benefit of examining count data from historic research sites is the potential availability of additional data that can be used to assess correlates of population change. Historic data sets from the boreal region could be a valuable source of information to identify correlates associated with avian population change because many previous studies were designed to examine avian-habitat relationships (see review by Schieck and Song 2006) and include detailed vegetation measurements. Therefore, these data facilitate repeat measurements of avian abundance as well as vegetation composition and structure.

We revisited historic research sites surveyed in the early to mid-1990s (Hobson and Bayne 2000a,b,c, Kirk and Hobson 2001) to evaluate the population trends for 10 common boreal songbird species breeding in the southern mixedwood forest of central Saskatchewan, Canada over $\sim 20$ years. Our objectives were: (1) to test whether any observed changes in abundance correlate with within-stand factors (forest succession or habitat change, e.g., stand height, tree species composition, disturbance), (2) to determine if trends remain after accounting for local habitat change and (3) to examine the correspondence between trend estimates derived from local surveys and those derived from regional BBS data. In the aspen-dominated boreal mixedwood forests of western Canada, the proportion of stands comprising coniferous species tends to increase as the stand matures, resulting in a concomitant change in the abundance of birds associated with coniferous habitat (Kirk et al. 1997, Hobson and Bayne 2000c, Cumming and Diamond 2002). Furthermore, because most species show distinct preferences for specific stand age classes (Hobson and Bayne 2000a, Cumming and Diamond 2002), we hypothesized that changes in stand age classes and composition away from those conditions in which a given species typically reaches its maximum abundance would result in declines in species abundance and vice versa. We therefore hypothesized that (all else being equal) species that are most abundant in young (15-25 yr; e.g., White-throated Sparrow [Zonotrica albicollis]) or mature forests (50-60 yr; e.g., Ovenbird [Seiurus aurocapilla]) should have negative trends in stands originally classified as old forest ( $80-110 \mathrm{yr}$ ). In contrast, we hypothesized that species that benefit from increasing amounts of coniferous trees should have positive or neutral trends in forest stands formerly classified as young or mature depending on changes in stand composition. For example, we hypothesized that Ovenbird, which reaches maximum densities in mature forests in Saskatchewan (Hobson and Bayne 2000a, Cumming and Diamond 2002), should have negative trends in stands transitioning to old forest. We also hypothesized that trends in mature forest species (e.g., Swainson's Thrush [Catharus ustulatus], Yellow-rumped Warbler [Setophaga 
Table 1. Hypothesized influence of covariates on local trends in abundance for 10 bird species in the aspen-dominated boreal mixedwood forests of central Saskatchewan.

\begin{tabular}{|c|c|c|c|c|c|c|c|c|}
\hline \multirow[b]{2}{*}{ Type of species } & \multirow[b]{2}{*}{ Species } & \multirow[b]{2}{*}{$\begin{array}{c}\text { Disturbance } \\
(\%)\end{array}$} & \multirow[b]{2}{*}{$\begin{array}{l}\text { Increase in } \\
\text { conifer }(\%)\end{array}$} & \multirow[b]{2}{*}{$\begin{array}{l}\text { Change in } \\
\text { height }(\mathrm{m})\end{array}$} & \multirow[b]{2}{*}{$\begin{array}{l}\text { Protected } \\
\text { area }\end{array}$} & \multicolumn{2}{|c|}{ Stand age $^{\dagger}$} & \multirow[b]{2}{*}{ Windthrow } \\
\hline & & & & & & Young & Old & \\
\hline \multirow{6}{*}{$\begin{array}{l}\text { Closed forest } \\
\text { species }\end{array}$} & Red-eyed Vireo & & - & + or $-\ddagger$ & & + & - & \\
\hline & Ruby-crowned Kinglet & & + & + or $-{ }^{\ddagger}$ & & + & - & \\
\hline & Swainson's Thrush & - & + & + & + & + & & - \\
\hline & Ovenbird & - & - & + or $-^{*}$ & + & + & - & - \\
\hline & Yellow-rumped Warbler & & + & & & + & & \\
\hline & Chipping Sparrow & & + & & & & & \\
\hline \multirow{4}{*}{$\begin{array}{l}\text { Plausible gap or } \\
\text { edge species }\end{array}$} & Hermit Thrush & & & + or $-\ddagger$ & & & & + \\
\hline & Mourning Warbler & + & - & + or $-{ }^{\ddagger}$ & & & - & + \\
\hline & Magnolia Warbler & & $t^{\S}$ & & & + & & + \\
\hline & White-throated Sparrow & + & - & & & & - & + \\
\hline
\end{tabular}

Stand age during the historic surveys conducted in the early to mid-1990s.

The predicted effect on trend could be positive if the prior stand age was young and negative if prior stand age was old.

${ }^{\S}$ Via a hypothesized correlated increase in coniferous shrubs.

coronata]) would be negatively associated with proportional decreases in the original stand area. In addition, we hypothesized that species associated with deciduous forests (e.g., Whitethroated Sparrow) would be negatively associated with increased cover of coniferous trees. We provide species-by-species predictions of positive vs. negative associations with our measured habitat variables in Table 1.

\section{METHODS}

\section{Study area}

Our study was conducted in and around Prince Albert Model Forest ( $53^{\circ} 50^{\prime} \mathrm{N}, 105^{\circ} 50^{\prime} \mathrm{W}$ ) as well as the Lac La Ronge region $\left(56^{\circ} 06^{\prime} \mathrm{N}, 105^{\circ} 17^{\prime} \mathrm{W}\right)$ within the boreal mixedwood forest of central Saskatchewan, Canada (Fig. 1). The majority of the study area lies in the mid-boreal upland ecoregion of the Boreal Plains ecozone; however, six forest stands were in the Churchill River Upland ecoregion along the southern periphery of the Boreal Shield ecozone (Acton et al. 1998; Fig. 1). The study area overlapped Prince Albert National Park as well as Lac La Ronge Provincial Park (Fig. 1), which are largely undeveloped, but the landscape surrounding those parks is a mosaic of upland forests in which commercial forestry operations are the principal land use, and lowland forests, which comprise primarily bogs and fens. Fire has historically been the dominant stand-replacing disturbance within the region, along with clearcut forest harvesting practices since the mid-1980s, primarily within the mid-boreal upland and to a lesser extent the Churchill River upland (Acton et al. 1998, Van Wilgenburg and Hobson 2008).

We selected the study sites from aspen-dominated (Populus tremuloides; $50-75 \%$ hardwood) mixedwood stands originally surveyed for avian abundance and community composition in June 1993 through 1996 (Hobson and Bayne 2000a,b, Kirk and Hobson 2001). The stands we studied were originally selected to examine avian-habitat relationships with stand age (Hobson and Bayne 2000a) and forest composition (Hobson and Bayne 2000c) and thus represented a gradient from early successional to oldgrowth forest of varying mixtures of deciduous and coniferous trees. We conducted an a priori power analysis using the original data set that suggested we needed approximately $40-50$ stands to detect a $30 \%$ change in abundance. We therefore selected 45 out of 71 possible stands that maximized the abundance of mixedwood-associated bird species in the original surveys for which we could accurately locate the original survey locations. Stand ages of the sites selected for resampling in 2014 were primarily old ( $80-110 \mathrm{yr}, N=23)$ or mature $(50-60 \mathrm{yr}, N=15)$ during the initial sampling, and a minority of the stands was originally in early regeneration $(15-25 \mathrm{yr}, N=7)$. Of the 45 selected study sites revisited in $2014,24(\sim 53 \%)$ had experienced disturbances since the original surveys: 12 with anthropogenic disturbance (i.e., forest harvesting), 9 with windthrow events, and 3 with forest fires.

Fig. 1. Location of the study area in the boreal forest of Canada (inset) and locations of forest stands sampled for avian abundance in 1994 and 2014 in the boreal mixedwood forest of central Saskatchewan.

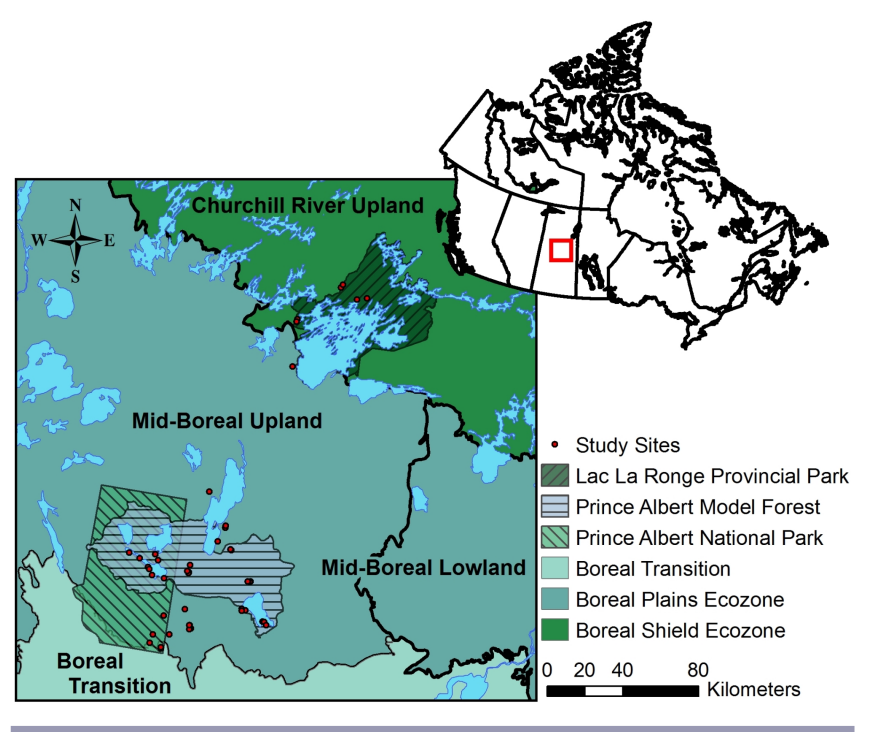




\section{Avian surveys}

Avian surveys completed circa 1994 were 10-min point-counts conducted between 04:00 and 09:00 h by experienced observers (Hobson and Bayne 2000a,b,c). Point-count stations were established with minimum distances of $250 \mathrm{~m}$ between stations and $100 \mathrm{~m}$ from a stand edge. All point-counts were unlimited distance radius; however, observers only counted birds that were estimated to be within the stand and were not previously recorded on adjacent point-count stations.

During June 2014, we surveyed the original point-count locations twice using similar protocols to those used by Hobson and Bayne (2000 a,b,c). However, following Matsuoka et al. (2012, 2014) we also estimated distances to vocalizing birds $(0-50,51-100$, and $>$ $100 \mathrm{~m}$ ) to allow us to account for distance-related detection error and to adjust both current and historic counts to densities. We made the simplifying assumption that distance-related detection error is primarily driven by interspecific differences in vocalizations and ignored potential differences in observer or habitat-related variation and changes through time.

We supplemented the survey data set with annually or semiannually replicated surveys that are part of ongoing bird monitoring within Prince Albert National Park (2005-2012). The monitoring program consists of 12 survey routes with a median of 15 point-count stations each (range: 6-26 stations), with each station separated by $\sim 500 \mathrm{~m}$. At each station, Parks Canada conducts 10-min unlimited radius point-counts using E-3A bioaccoustic monitoring kits (RiverForks Research, Chilliwack, British Columbia, Canada) to make stereo recordings during the same morning survey period as our study (Hobson et al. 2002b). Recordings were transcribed by two of the observers involved in our study. These data were used in the trend analysis to increase the sample size for estimating overall change in mean abundance, as well as to better reflect the interannual variation in species counts.

For each of the species for which we generated trend estimates, we also obtained trend estimates derived for the same BBS stratum within which our study area is located (i.e., Boreal Taiga Plains [BCR 6] of Saskatchewan). Specifically, we obtained trend estimates for the 1994-2014 period from the Canadian BBS analysis (A. Smith, unpublished analysis) against which we compared estimates from our fixed year effects estimates using Pearson correlation. The Saskatchewan BCR 6 stratum has data from 28 BBS routes (with 1-33 yr of data). However, sample sizes in BBS trend analyses vary between 10 and 75 routes for the species we examined depending on the contribution of information from adjacent strata and the number of routes with nonzero counts (Smith et al. 2014).

\section{Land-cover analysis}

We generated $100 \mathrm{~m}$ radius buffers around the geographic coordinates of each point-count location using a geographic information system (ArcGIS version 10.1, ESRI, Redlands, California, USA). Within each buffer, we quantified the change in forest cover between $\sim 1994$ and 2014. We used moderate resolution $(30 \mathrm{~m})$ imagery to digitize all areas of forest change. Specifically, we obtained Landsat satellite imagery from two eras: three Landsat 5 Thematic Mapper (TM) scenes from 1993 and two Landsat 8 Operational Land Imager and Thermal Infrared
Sensor scenes from 2014 (Table 2). Two Landsat TM Mosaics (1984-1997) were used to verify the digitized forest boundaries for the original $(\sim 1994)$ surveys. To verify the digitized stand boundaries for our 2014 surveys, we used either $62.5 \mathrm{~cm}$ resolution color orthophotos from the Saskatchewan Geospatial Imagery Collaborative ( $N=199$ point-count stations) collected between 2008 and 2011 (FlySask version 2.0, http://www.flysask.ca/) or $2.5 \mathrm{~m}$ resolution SPOT satellite imagery $(N=87$ point-count stations; Hoover 2012). Prior to all analyses, all geographic data were converted to an Albers Equal Area Conic (Canada) projection to ensure accurate representation of area-based metrics.

Table 2. Landsat sensor, path and row numbers, and acquisition dates of Landsat images used.

\begin{tabular}{|c|c|c|c|}
\hline Sensor & Path & Row & $\begin{array}{l}\text { Acquisition } \\
\text { date }\end{array}$ \\
\hline Thematic Mapper & 38 & 21 & 15 June 1992 \\
\hline Thematic Mapper & 38 & 22 & 15 June 1992 \\
\hline Thematic Mapper & 38 & 22 & $\begin{array}{l}\text { 22 September } \\
1993\end{array}$ \\
\hline $\begin{array}{l}\text { Landsat } 8 \text { Operational Land Imager } \\
\text { and Thermal Infrared Sensor }\end{array}$ & 38 & 21 & 30 July 2014 \\
\hline $\begin{array}{l}\text { Landsat } 8 \text { Operational Land Imager } \\
\text { and Thermal Infrared Sensor }\end{array}$ & 38 & 22 & 14 July 2014 \\
\hline
\end{tabular}

To determine the change in forest cover in each buffer, we first identified the area of forest cover for 1994. To determine the area of forest cover in 2014, we determined the area of disturbance in 2014 and subtracted this value from the 1993 value and thus derived forest change as the difference in area between the two periods. To this end, we derived land-cover classifications using Iso Cluster unsupervised classification (Ball and Hall 1965) for both periods from Landsat satellite imagery. Iso Cluster analysis identified 15 land-cover classes, which were subsequently reclassified into a binary forest vs. nonforest product. We manually identified disturbed areas within each point-count buffer by on-screen digitization of polygons around areas of obvious nonforested features (e.g., water, roads, cleared land). Because of the lower resolution of the earlier (1993) Landsat images, we maintained a scale of 1:10,000 when deciding on disturbance boundaries, and a scale of 1:4000 for the later images. For the later images, we used FlySask orthophotos (FlySask v2.0) as our primary approximation of disturbance because they are higher resolution than the Landsat images. All disturbance polygons were subsequently intersected with their respective buffers, and the amount of area disturbed was calculated per station and time period. We then calculated the percentage of forest change relative to the initial sampling period for each pointcount station (percent disturbed; hereafter PD).

\section{Vegetation sampling}

We repeated vegetation measurements conducted in $\sim 1994$ (Hobson and Bayne 2000c) by visually estimating vegetation structure and composition within a $25 \mathrm{~m}$ radius around each point-count location ( $\sim .2$ ha). Specifically, we quantified stand height and canopy composition. To ground-truth canopy height estimates, a minimum of three of the tallest trees per point-count station were measured using a clinometer in 2014; in 1994, two 
Table 3. Estimated change in avian abundance in deciduous-dominated mixedwood stands of central Saskatchewan from revisits to historic research sites (circa 2004, 2014) estimated from generalized linear mixed-effects models compared with trends from the North American Breeding Bird Survey (Boreal Taiga Plains stratum). Upper and lower CIs denote Bayesian credible intervals.

\begin{tabular}{|c|c|c|c|c|c|c|c|c|c|}
\hline \multirow[b]{3}{*}{ Species } & \multicolumn{6}{|c|}{ Local surveys of historic research sites } & \multicolumn{3}{|c|}{ Breeding Bird Survey trend $(\% / y r)$} \\
\hline & \multicolumn{3}{|c|}{ Annual trend $(\% / y r)$} & \multicolumn{3}{|c|}{ Change (\%) 1994-2014 } & \multirow[b]{2}{*}{ Lower CI } & \multirow[b]{2}{*}{ Median } & \multirow[b]{2}{*}{ Upper CI } \\
\hline & Lower CI & Median & Upper CI & Lower CI & Median & Upper CI & & & \\
\hline Red-eyed Vireo & -2.83 & -1.26 & -0.01 & -43.7 & -22.3 & -0.3 & -0.73 & 0.25 & 1.52 \\
\hline Ruby-crowned Kinglet & -5.31 & -3.06 & -0.93 & -66.4 & -46.3 & -17.0 & -3.55 & 0.55 & 4.28 \\
\hline Swainson's Thrush & -0.89 & 0.61 & 2.12 & -16.4 & 13.0 & 52.1 & -4.34 & 0.60 & 6.18 \\
\hline Hermit Thrush & -1.17 & 0.61 & 2.53 & -21.0 & 13.0 & 64.9 & -2.24 & 2.25 & 6.74 \\
\hline Ovenbird & -6.09 & -4.55 & -3.24 & -71.5 & -60.6 & -48.2 & -2.96 & -0.68 & 2.86 \\
\hline Mourning Warbler & 3.96 & 6.97 & 10.12 & 117.3 & 285.0 & 588.0 & -5.57 & -2.56 & 0.58 \\
\hline Magnolia Warbler & 2.95 & 4.64 & 6.52 & 79.0 & 147.9 & 253.6 & -8.59 & -1.96 & 4.12 \\
\hline Yellow-rumped Warbler & -6.18 & -4.71 & -3.09 & -72.1 & -61.9 & -46.6 & -4.16 & -0.95 & 1.62 \\
\hline Chipping Sparrow & -4.57 & -3.61 & -2.05 & -60.8 & -52.1 & -33.9 & -3.68 & -1.53 & 0.74 \\
\hline White-throated Sparrow & 1.91 & 3.22 & 4.52 & 46.1 & 88.4 & 141.9 & -1.35 & -0.17 & 0.98 \\
\hline
\end{tabular}

trees in each of four 0.04-ha circular plots per point-count station were measured (Bayne et al. 2010). We visually estimated average canopy height to the nearest $0.5 \mathrm{~m}$ based on the height relative to the measured subset of trees. Forest canopy composition was determined by visually estimating the proportion of the forest canopy composed of individual tree species to the nearest $10 \%$. The presence or absence of any windthrow events beyond normal tree mortality or canopy gaps within the point-count radius was recorded. We distinguished windthrow based in part by uniform aging or decay and common directionality of the downed trees.

\section{Vegetation summaries}

Forest birds respond strongly to the proportion of forest canopy composed of coniferous trees (Bayne et al. 2010), and succession would likely result in changes in this proportion. We therefore calculated the change in the percentage of the canopy composed of coniferous trees (hereafter PC) by subtracting the 1994 proportion of the stand composed of conifers from the estimated 2014 proportion. In addition, we estimated change in stand height (hereafter $\Delta \mathrm{Ht}$ ) as a metric of habitat change by calculating the absolute differences in stand height between those measured in $\sim 1994$ and those measured in 2014 .

\section{Statistical analysis}

We selected the 10 most abundant songbird species (Table 3) for analysis. Following Hobson and Bayne (2000a,b,c), we took the maximum count across visits as our metric of abundance because it has previously been shown to relate well to density (Toms et al. 2006), and preliminary multinomial Poisson mixture models (Royle and Dorazio 2006) suggested that the detection probability did not differ between survey periods (within-year visits). Because some error may occur in accurately and precisely relocating the exact location of point-count stations $20 \mathrm{yr}$ after their initial survey, we treated forest stands as our sampling unit for analysis. We therefore summed counts for a given species across all pointcount stations within a stand and treated this as our sampling unit.

We estimated change in forest bird abundance by modeling species counts using generalized linear mixed-effects models (GLMM; Zuur et al. 2009), treating year as a fixed effect and estimating separate random slopes (for year) and intercepts for each forest stand. We selected between Poisson, negative binomial, zeroinflated Poisson, and zero-inflated negative binomial error structures using the Akaike Information Criterion (AIC) and assessed model adequacy by examining residual Q-Q plots and histograms for normality and plots of residuals vs. fitted values for homogeneity (Zuur et al. 2009). We included the natural logarithm of the number of point-count stations within a stand as an offset to account for between-site and between time period variations in survey effort. We used a pseudo-Bayesian GLMM as implemented in the glmmADMB package (Fournier et al. 2012, Skaug et al. 2015) within the $\mathrm{R}$ (version 3.1.1) statistical computing environment ( $\mathrm{R}$ Core Team 2014). We estimated trends and $95 \%$ credible intervals from the posterior distribution of the fixed year effect and saved random slope parameters for each site for further analysis.

We compared our trend estimates against those derived from the BBS for BCR 6 over the same (1994-2014) time frame that our data covered (A. Smith, unpublished analysis) using Pearson correlation. We visually compared graphed estimates from our fixed-year effects estimates against the BBS estimates and compared the sign of the estimates as well as overlap (or lack thereof) of the $95 \%$ credible intervals.

We used general linear models to test for relationships between changes in stand-level characteristics and changes in avian abundance. We treated the stand-level random slopes from our GLMMs as a response variable in seven or eight a priori candidate models (Table 4) depending on whether the species examined was associated with closed-canopy forests or canopy gaps and forest edges (Poole 2005). Our candidate models included a null (intercept only) model and up to two main effects. To avoid overparameterization, we only included an interaction in a model containing $\Delta \mathrm{Ht}$ because $\Delta \mathrm{Ht}$ was caused, in part, by disturbance of the forest canopy. We therefore modeled bird responses to $\Delta \mathrm{Ht}$ by including main effects for $\Delta \mathrm{Ht}$ and a factor representing the presence of any disturbance (e.g., fire, forest harvest, windthrow) in the stand, as well as the interaction between disturbance and $\Delta \mathrm{Ht}$ to capture covariation in disturbance and $\Delta \mathrm{Ht}$. For species suspected as being associated with canopy gaps and forest edges, species could either respond positively to PD or to within-stand 
Table 4. A priori candidate models examining variation in stand-level trends in forest bird abundance between circa 1994 and 2014. $\mathrm{PD}=$ proportional change in original stand area, $\Delta \mathrm{PC}=$ change in proportion of canopy composed of coniferous trees, Dist. $=$ disturbance, $\Delta \mathrm{Ht}=$ change in stand height.

\begin{tabular}{|c|c|c|}
\hline Type of species & Model structure & Model name \\
\hline Closed forest species & 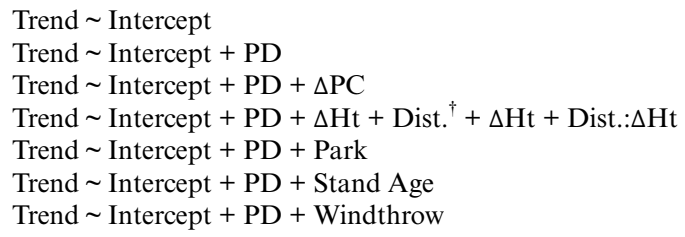 & $\begin{array}{l}\text { Null } \\
\text { Proportion disturbed } \\
\text { Change in conifer cover } \\
\text { Change in height } \\
\text { Protected areas } \\
\text { Stand age } \\
\text { Windthrow }\end{array}$ \\
\hline Gap or edge associated species & $\begin{array}{l}\text { Trend } \sim \text { Intercept } \\
\text { Trend } \sim \text { Intercept }+\Delta \mathrm{PC} \\
\text { Trend } \sim \text { Intercept }+\Delta \mathrm{Ht}+\text { Dist. }+\Delta \mathrm{Ht}+\text { Dist.: } \Delta \mathrm{Ht} \\
\text { Trend } \sim \text { Intercept }+ \text { Park } \\
\text { Trend } \sim \text { Intercept }+ \text { Stand Age } \\
\text { Trend } \sim \text { Intercept }+ \text { Windthrow } \\
\text { Trend } \sim \text { Intercept }+\Delta \mathrm{PC}+\text { Windthrow } \\
\text { Trend } \sim \text { Intercept }+\Delta \mathrm{PC}+\text { Stand Age }\end{array}$ & $\begin{array}{l}\text { Null } \\
\text { Change in conifer cover } \\
\text { Change in height } \\
\text { Protected areas } \\
\text { Stand age } \\
\text { Windthrow } \\
\text { Conifer cover }+ \text { windthrow } \\
\text { Conifer cover + stand age }\end{array}$ \\
\hline
\end{tabular}

Disturbance coded as disturbed (1) vs. undisturbed (0).

changes associated with canopy composition and gap creation. We therefore first tested this assumption by comparing the fit of the PD model against the null model; if the PD model received more support than the null model, we then fit "closed forest species" candidate models to the data (Table 4). Conversely, if there was little support for the PD model, we fit a suite of models for gap- or edge-associated species (Table 4) that we assumed would capture within-stand changes in both the structure and composition of the canopy and shrub layers (Table 1). For species associated with closed canopy forests, we included the PD relative to the original stand boundaries in all models except the null (Table 4). We also included $\Delta \mathrm{PC}, \Delta \mathrm{Ht}$, a factor indicating whether the stand was within a protected area (hereafter Park), a factor indicating whether the stand had experienced a windthrow event, and factors to represent whether the original stand age class was old (1) vs. young or mature (0) as candidate variables.

We used AIC with second-order bias correction ( $\mathrm{AIC}_{\mathrm{c}}$ ) and model weights to rank our competing models (Burnham and Anderson 2002). We screened out models with uninformative parameters or "pretending" variables (see Anderson 2008) if the $85 \%$ confidence intervals overlapped zero (Arnold 2010) and there was little evidence for a change in deviance (Anderson 2008). If no single model received $>85 \%$ of the support based on $\mathrm{AIC}_{\mathrm{c}}$ weights, we generated a "confidence" set consisting of the models that contained a cumulative $85 \%$ of the $\mathrm{AIC}_{\mathrm{c}}$ weight (Burnham and Anderson 2002). Recent work has cautioned that model averaging of parameter estimates can result in bias if the variables involved display even relatively minor correlation (Freckleton 2011, Cade 2015), and Cade (2015) recommends the discontinuation of model averaging that ignores covariance. Therefore, we based inference on a single model created by combining all parameters from the models within the confidence set. We conducted $\mathrm{AIC}_{\mathrm{c}}$ model selection using the AICcmodavg package (Mazerolle 2014).

\section{RESULTS}

Eight of the 10 species showed evidence of substantial changes in abundance, with only Swainson's Thrush and Hermit Thrush
(Catharus guttatus) showing no evidence of change (Tables 3 and 5 ) over the $\sim 20$-yr study period. Five species showed marked declines in abundance, with median estimated declines of $\sim 22$ $62 \%$ over 20 yr (Table 3 ). Declining species included (in order of steepest to shallowest decline): Yellow-rumped Warbler, Ovenbird, Chipping Sparrow (Spizella passerina), Ruby-crowned Kinglet (Regulus calendula), and Red-eyed Vireo (Vireo olivaceus; Table 3). In contrast, Mourning Warbler (Geothlypis philadelphia), Magnolia Warbler (Setophaga magnolia), and White-throated Sparrow all had sizeable ( 88-285\%) increases in abundance between 1994 and 2014 (Table 3). Overall, trend estimates from our local surveys were not correlated with trend estimates from the BBS over the same time period $(r=-0.29, P$ $=0.41$; Fig. 2). Across species, BBS trends from the Boreal Plains ecozone of Saskatchewan were more negative $($ mean $=-0.42$, standard deviation $[\mathrm{SD}]=1.42$ ) on average than our local surveys (mean $=-0.11, \mathrm{SD}=4.06)$. Trend estimates from our local surveys were more precise than those from the BBS for 7 of the 10 species (Table 3), with a mean difference in the range of the $95 \%$ confidence intervals of 3.21 (Fig. 2).

Examination of factors associated with within-stand trends in abundance of the 10 species in 45 aspen-dominated boreal mixedwood stands for which we had both estimated rates of change in bird abundance and detailed vegetation data indicated that only Ovenbird and Magnolia Warbler had a single top model based on $\mathrm{AIC}_{\mathrm{c}}$ model selection (Appendix 1). After eliminating models containing uninformative parameters (Appendix 2), none of the species showed strong evidence for differences in trends between protected areas and the surrounding landscape after accounting for other variables (Table 6).

Several species showed evidence that within-stand changes in abundance were related to changes in forest cover. Both Red-eyed Vireo and Hermit Thrush responded similarly to a proportional change in forest cover within the stand (Fig. 3, Table 6) that suggested that the abundance of both species increased in stands that were disturbed. In contrast, both Swainson's Thrush (Fig. 4A) and Yellow-rumped Warbler (Fig. 4B) abundances remained 
Table 5. Generalized linear mixed effects model results examining variation in abundance of 10 species of passerine between circa 1994 and 2014 in aspen-dominated mixedwood forests of central Saskatchewan.

\begin{tabular}{|c|c|c|c|c|c|c|c|c|c|}
\hline \multirow[b]{2}{*}{ Species } & \multirow[b]{2}{*}{ Factor } & \multicolumn{4}{|c|}{ Fixed effects } & \multicolumn{2}{|c|}{ Random effects } & \multirow[b]{2}{*}{$\begin{array}{l}\text { Dispersion } \\
\text { parameter }\end{array}$} & \multirow[b]{2}{*}{$\mathrm{SE}^{\dagger}$} \\
\hline & & $\beta$ & $\mathrm{SE}^{\dagger}$ & $\bar{Z}$ & $P$ & Variance & $\overline{\mathrm{SD}^{\ddagger}}$ & & \\
\hline \multirow[t]{2}{*}{ Red-eyed Vireo } & Intercept & 0.02 & 0.13 & 0.20 & 0.84 & 0.34 & 0.58 & 8.71 & 2.99 \\
\hline & Year & -0.01 & 0.01 & -1.65 & 0.10 & $1.25 \times 10^{-3}$ & 0.04 & & \\
\hline \multirow[t]{2}{*}{ Ruby-crowned Kinglet } & Intercept & -1.09 & 0.17 & -6.61 & $<0.001$ & 0.54 & 0.73 & N/A & \\
\hline & Year & -0.03 & 0.01 & -3.07 & $<0.005$ & $9.06 \times 10^{-4}$ & 0.03 & & \\
\hline \multirow{2}{*}{ Swainson's Thrush } & Intercept & -0.56 & 0.16 & -3.59 & $<0.001$ & 0.47 & 0.69 & 4.20 & 1.26 \\
\hline & Year & 0.00 & 0.01 & 0.27 & 0.79 & $2.99 \times 10^{-4}$ & 0.02 & & \\
\hline \multirow[t]{2}{*}{ Hermit Thrush } & Intercept & -1.52 & 0.22 & -6.84 & $<0.001$ & 1.31 & 1.14 & 18.21 & 17.13 \\
\hline & Year & 0.00 & 0.01 & 0.48 & 0.63 & $1.44 \times 10^{-3}$ & 0.04 & & \\
\hline \multirow[t]{2}{*}{ Ovenbird } & Intercept & 0.89 & 0.07 & 12.01 & $<0.001$ & 0.13 & 0.36 & 68.10 & 50.48 \\
\hline & Year & -0.05 & 0.01 & -6.15 & $<0.001$ & $1.87 \times 10^{-3}$ & 0.04 & & \\
\hline \multirow[t]{2}{*}{ Mourning Warbler } & Intercept & -2.82 & 0.28 & -10.02 & $<0.001$ & 0.40 & 0.63 & 7.63 & 3.98 \\
\hline & Year & 0.07 & 0.02 & 4.53 & $<0.001$ & $1.37 \times 10^{-3}$ & 0.04 & & \\
\hline \multirow[t]{2}{*}{ Magnolia Warbler } & Intercept & -1.79 & 0.19 & -9.51 & $<0.001$ & 0.66 & 0.81 & N/A & \\
\hline & Year & 0.05 & 0.01 & 4.68 & $<0.001$ & $1.21 \times 10^{-3}$ & 0.03 & & \\
\hline \multirow{2}{*}{ Yellow-rumped Warbler } & Intercept & -0.02 & 0.13 & -0.12 & 0.90 & 0.14 & 0.37 & 3.35 & 0.94 \\
\hline & Year & -0.05 & 0.01 & -5.35 & $<0.001$ & $1.93 \times 10^{-4}$ & 0.01 & & \\
\hline \multirow[t]{2}{*}{ Chipping Sparrow } & Intercept & -0.22 & 0.12 & -1.83 & 0.07 & 0.40 & 0.63 & N/A & \\
\hline & Year & -0.04 & 0.01 & -5.78 & $<0.001$ & $5.39 \times 10^{-4}$ & 0.02 & & \\
\hline \multirow[t]{2}{*}{ White-throated Sparrow } & Intercept & -0.48 & 0.11 & -4.58 & $<0.001$ & 0.18 & 0.42 & 33.08 & 17.78 \\
\hline & Year & 0.03 & 0.01 & 4.41 & $<0.001$ & $1.38 \times 10^{-3}$ & 0.04 & & \\
\hline
\end{tabular}

${ }^{\dagger}$ Standard error.

${ }^{\ddagger}$ Standard deviation.

Fig. 2. Comparison between trend estimates derived from revisits to historic (circa 1994) research sites in the boreal mixedwood forests of central Saskatchewan and trends derived from the North American Breeding Bird Survey (1994-2014) for Bird Conservation Region 6 (Boreal Plain ecozone). Error bars denote $95 \%$ credible intervals around median trends.

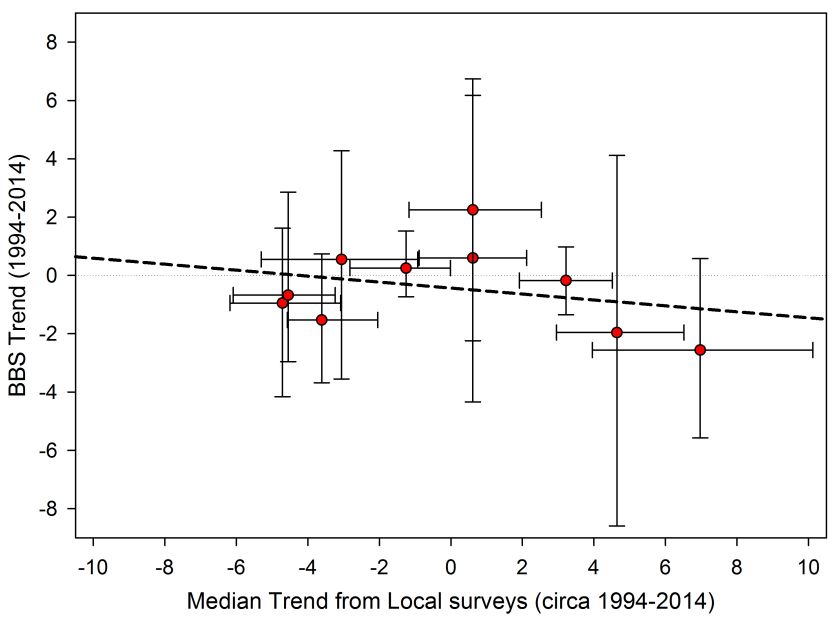

stable in stands without stand-replacing disturbances but declined within stands that had a decreased proportion of forest cover compared to 1994 (Table 6). The selected model for Chipping Sparrow also suggested its abundance decreased with proportional declines in stand area; however, there was also
Fig. 3. Within-stand trends in abundance of Red-eyed Vireo (A) and Hermit Thrush (B) and predicted relationship (solid lines, with $85 \%$ confidence intervals [dashed lines]) with proportional change in forest cover between circa 1994 and 2014. Percent annual change can be derived by multiplying the y-axis by 100 .

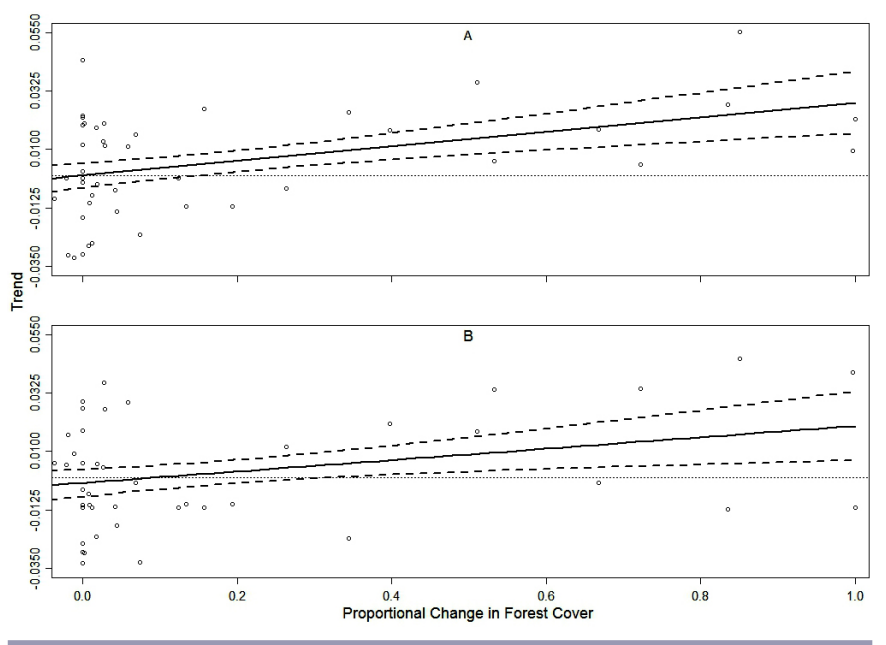

support for a model including stand age (Appendix 1). Our model suggested that Chipping Sparrow abundance remained stable in stands without loss of forest cover but that abundance declined with reductions in forest cover (Fig. 5, Table 6). However, our model also suggested that declines in abundance for this species were not as great in old forest stands as in young forest stands (Fig. 5, Table $6)$. 
Table 6. Parameter estimates from linear models examining variation in within-stand trends (circa 1994 to 2014) in abundance for 10 passerine species in aspen-dominated mixedwood forests of central Saskatchewan. Model coefficients ( $\beta$ ) and standard errors (SEs) are included for the covariates from the selected models. $\mathrm{PD}=$ proportional change in original stand area, $\triangle \mathrm{PC}=$ change in proportion of canopy composed of coniferous trees, Dist. $=$ disturbance (disturbed $=1$, undisturbed $=0), \Delta \mathrm{Ht}=$ change in stand height. Parameter values were rescaled by multiplying by a constant (100) for ease of presentation; divide by 100 to obtain estimates. None of the models contained coefficients for Windthrow or Park effects.

\begin{tabular}{|c|c|c|c|c|c|c|c|c|c|c|c|c|c|c|}
\hline \multirow[b]{2}{*}{ Species model } & \multicolumn{2}{|c|}{ Intercept } & \multicolumn{2}{|c|}{$\mathrm{PD}^{\dagger}$} & \multicolumn{2}{|c|}{$\Delta \mathrm{PC}$} & \multicolumn{2}{|c|}{ Stand age } & \multicolumn{2}{|c|}{$\Delta \mathrm{Ht}$} & \multicolumn{2}{|c|}{ Dist. } & \multicolumn{2}{|c|}{$\Delta \mathrm{Ht}$ :Dist. } \\
\hline & $\beta$ & $\mathrm{SE}$ & $\beta$ & SE & $\beta$ & SE & $\beta$ & SE & $\beta$ & $\mathrm{SE}$ & $\beta$ & SE & $\beta$ & SE \\
\hline Red-eyed Vireo & 0.00 & 0.32 & -2.81 & 0.93 & & & & & & & & & & \\
\hline Ruby-crowned Kinglet & -0.01 & 0.48 & -1.96 & 1.24 & & & & & 0.04 & 0.10 & -0.78 & 0.63 & 0.16 & 0.12 \\
\hline Swainson's Thrush & 0.26 & 0.10 & 1.00 & 0.29 & & & & & & & & & & \\
\hline Hermit Thrush & -0.21 & 0.36 & -2.19 & 1.04 & & & & & & & & & & \\
\hline Ovenbird & 4.38 & 1.00 & 3.00 & 2.56 & & & & & -0.50 & 0.20 & -5.13 & 1.30 & 0.55 & 0.24 \\
\hline Mourning Warbler & -1.47 & 0.67 & -0.75 & 1.71 & & & & & 0.11 & 0.14 & 2.42 & 0.87 & -0.08 & 0.16 \\
\hline Magnolia Warbler & -1.66 & 0.64 & & & & & & & 0.30 & 0.13 & 3.08 & 0.74 & -0.22 & 0.14 \\
\hline Yellow-rumped Warbler & 0.03 & 0.06 & 0.49 & 0.18 & & & & & & & & & & \\
\hline Chipping Sparrow & 0.16 & 0.17 & 1.56 & 0.42 & & & 0.36 & 0.25 & & & & & & \\
\hline White-throated Sparrow & -3.13 & 0.85 & & & -0.03 & 0.02 & 1.86 & 0.82 & 0.35 & 0.18 & 3.32 & 1.06 & -0.30 & 0.19 \\
\hline
\end{tabular}

${ }^{\dagger}$ Negative parameter values imply a positive relationship due to negative covariate values representing a decrease in stand area in the original age class.

Fig. 4. Swainson's Thrush (A) and Yellow-rumped Warbler (B) abundance (solid lines, with $85 \%$ confidence intervals [dashed lines]) decreased with greater proportional change in forest cover between circa 1994 and 2014. Percent annual change can be derived by multiplying the $y$-axis by 100 .

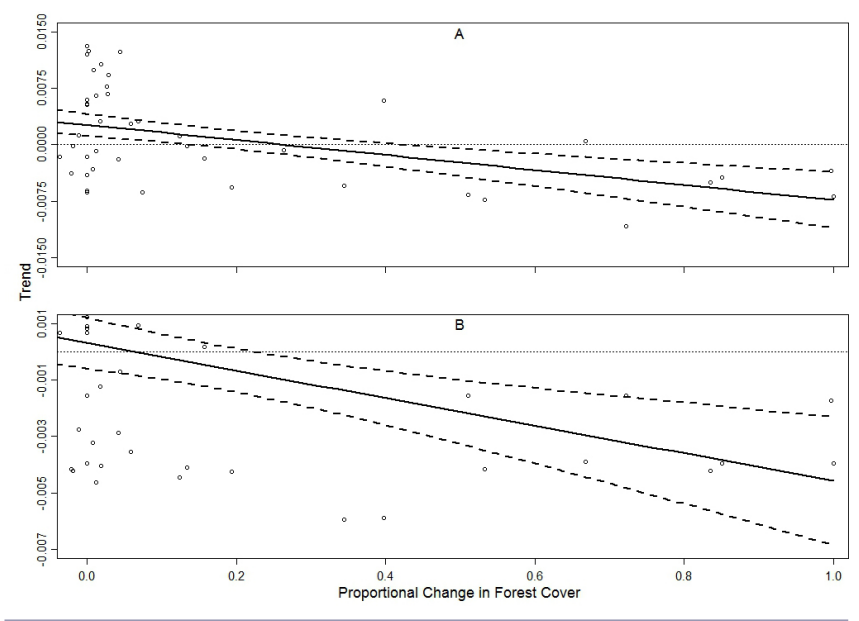

Five species showed evidence for a response to a change in stand height, specifically Ruby-crowned Kinglet, Ovenbird, Mourning Warbler, Magnolia Warbler, and White-throated Sparrow (Appendix 1). Although Ruby-crowned Kinglet had two models that outperformed the null model based on $\mathrm{AIC}_{\mathrm{c}}$ (Appendix 1), parameter estimates generated from those models had confidence intervals that overlapped zero (Table 6, Appendix 2) and thus only provided weak support for an influence of any of the factors we examined. Within-stand trends for Ovenbird abundance appeared to be influenced by several factors (Table 6), including a negative relationship with proportional decreases in the amount of forest cover within stands. Ovenbird abundance also changed in response to change in stand height (Table 6), with this response differing between disturbed and undisturbed stands (Fig. 6).
Fig. 5. Chipping Sparrow abundance decreased with greater proportional change in forest cover between circa 1994 and 2014 in old (blue squares and solid lines, with $85 \%$ confidence intervals [dashed lines]) vs. young or mature (open circles and black dotted lines, with $85 \%$ confidence intervals [dashed lines]) mixedwood stands. Percent annual change can be derived by multiplying the y-axis by 100 .

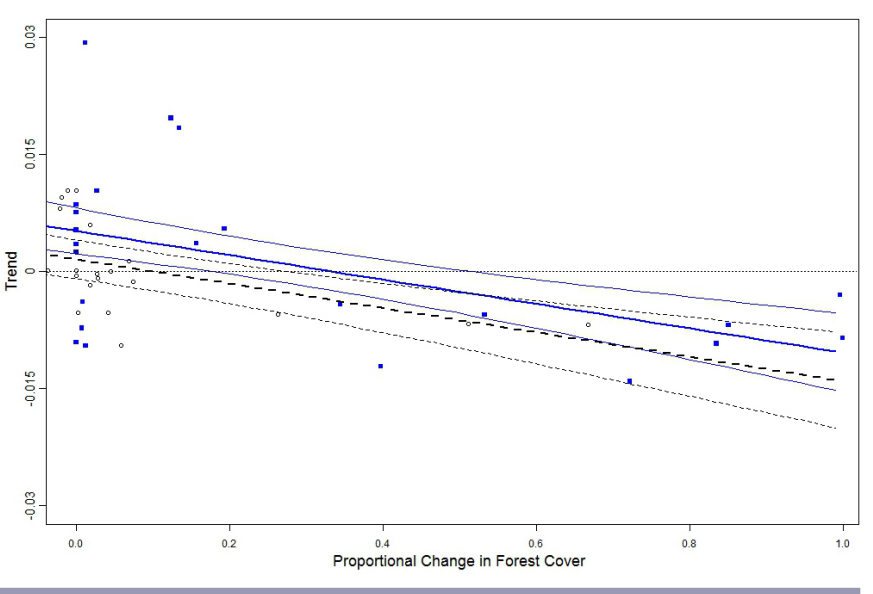

Ovenbird trends were generally positive in undisturbed stands, but decreased with increasing stand height, whereas the opposite was true of Ovenbird abundance in disturbed stands. Similar parameters were in the model for Mourning Warbler abundance; however, the only parameter with an $85 \%$ confidence interval that did not overlap zero was the factor for disturbance (Table 6), which suggests that the abundance of this species increased in disturbed stands and decreased in undisturbed stands (Fig. 7). Similarly, Magnolia Warbler abundance generally increased in disturbed stands and decreased in undisturbed stands (Fig. 8, Table 6). This response appeared to be mediated by forest growth because increased Magnolia Warbler abundance was correlated with increases in stand height in both disturbed and undisturbed forests (Fig. 8, Table 6). 
Fig. 6. Trends in Ovenbird abundance were generally negative but increased with increases in stand height in disturbed stands (blue squares and solid line, with $85 \%$ confidence intervals [dashed lines]), whereas trends in undisturbed stands were generally positive but decreased with increases in stand height (open circles and black dashed line, with $85 \%$ confidence intervals [dotted lines]) between circa 1994 and 2014.

Predictions were generated using parameter estimates in Table 5 while holding proportional change in forest cover constant at the mean. Stands were considered disturbed if we noted the presence of any disturbance (e.g., fire, forest harvest, or windthrow) in the stand.

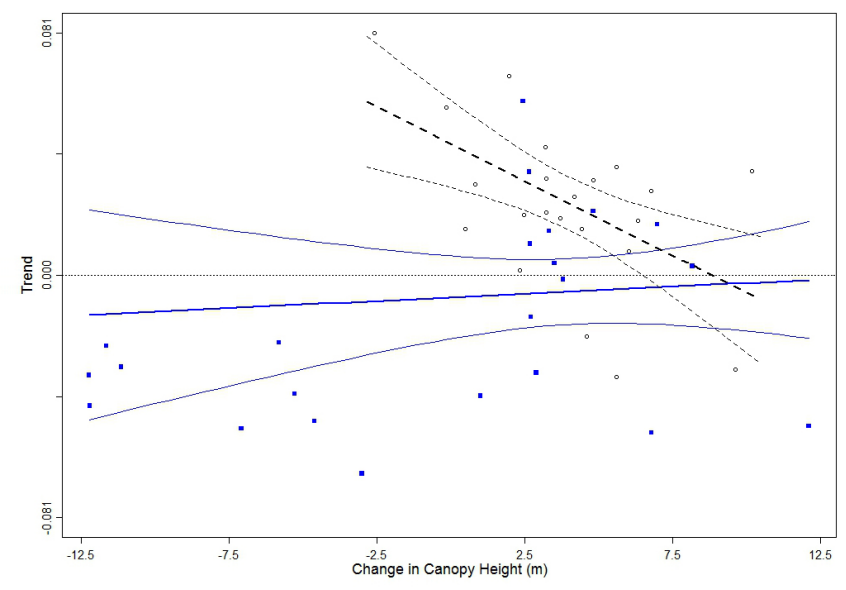

Fig. 7. Mourning Warbler abundance trends in undisturbed (decreasing) and disturbed (increasing) stands between circa 1994 and 2014. Boxplots depict median (solid line) and 25th to 75 th percentiles of the data (box), and whiskers are \pm 1.5 times the interquartile range. Stands were considered disturbed if we noted the presence of any disturbance (e.g., fire, forest harvest, or windthrow) in the stand.

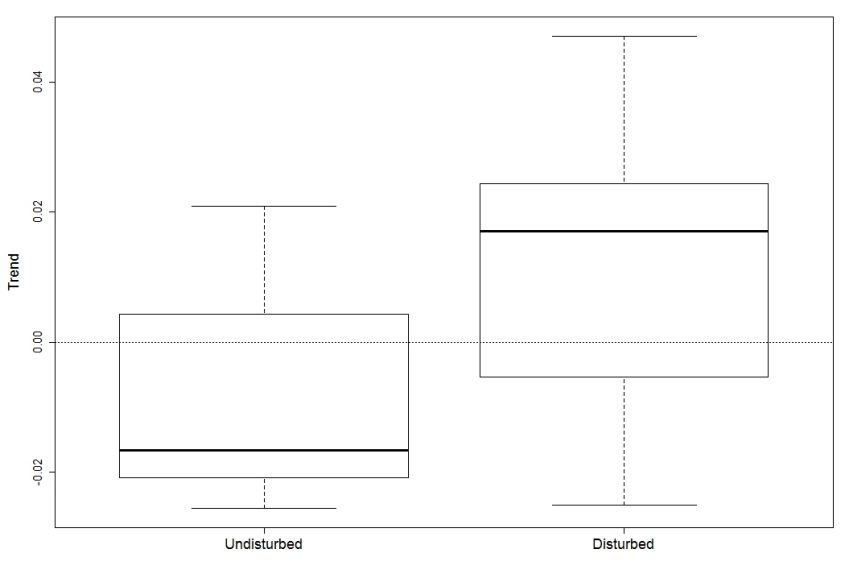

Fig. 8. Increasing trends (with $85 \%$ confidence intervals) in abundance of Magnolia Warbler with increasing stand height in disturbed (blue squares and solid line) and undisturbed (open circles and dashed line) mixedwood stands between circa 1994 and 2014. Stands were considered disturbed if we noted the presence of any disturbance (e.g., fire, forest harvest, or windthrow) in the stand.

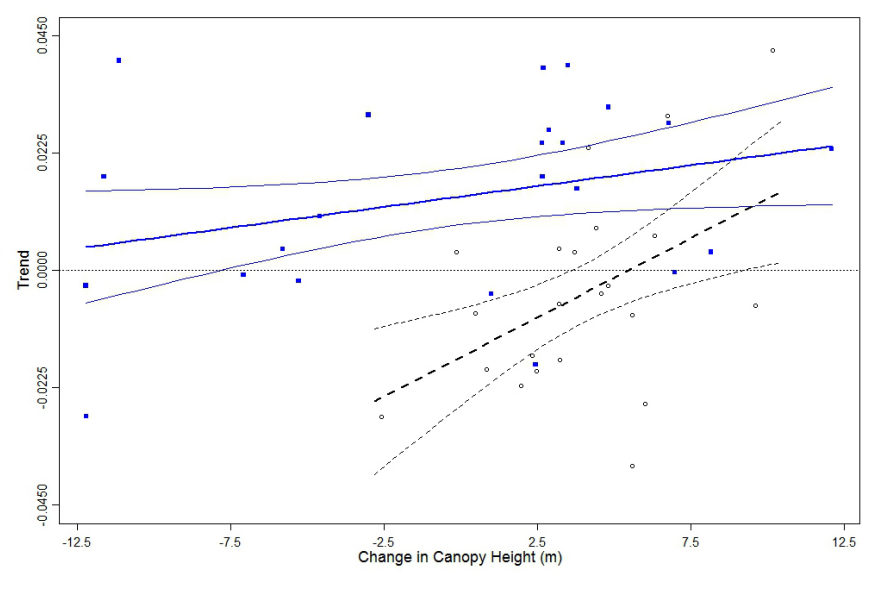

White-throated Sparrow showed evidence that changes in abundance were associated not only with change in stand height, but also stand age, change in conifer cover, and disturbance (Appendix 1). Our model (Table 6) suggests that within-stand trends in White-throated Sparrow abundance were negatively associated with increases in conifer cover. Model predictions suggest that trends in White-throated Sparrow abundance were greater in old stands than in young and mature stands (Fig. 9A vs. B). In both old stands and young-mature stands, our model suggests that White-throated Sparrow abundance generally increased in disturbed stands and decreased in undisturbed stands, but this effect was mitigated, in part, by increases in stand height (Fig. 9, Table 6).

\section{DISCUSSION}

For the suite of species we investigated, our results suggest that substantial changes in abundance have occurred over the past $\sim 20$ years. Eight of the ten species examined had significant changes in abundance across the study sites, with five having declined (Redeyed Vireo, Ruby-crowned Kinglet, Ovenbird, Yellow-rumped Warbler, and Chipping Sparrow), and three having increased (Mourning Warbler, Magnolia Warbler, and White-throated Sparrow). Variables representing forest succession were correlated with trends for most species, with the proportion change in original stand area over the study period appearing in the confidence set. Other changes in forest structure (e.g., change in canopy height, forest age) were also found to be important factors associated with trends for these species and together highlight the need to account for successional changes along with disturbance in assessing mechanisms for species' trends. 
Fig. 9. Increasing trends in abundance of White-throated Sparrow in old (A) and young and mature (B) mixedwood forest stands in response to increasing stand height and disturbance between circa 1994 and 2014. Blue squares and solid lines depict trends (with $85 \%$ confidence intervals [dotted lines]) in disturbed stands. Open circles and black dashed lines depict trends in undisturbed stands (with $85 \%$ confidence intervals [dotted lines]). Predictions were generated using parameter estimates in Table 5 while holding change in conifer cover constant at the median.

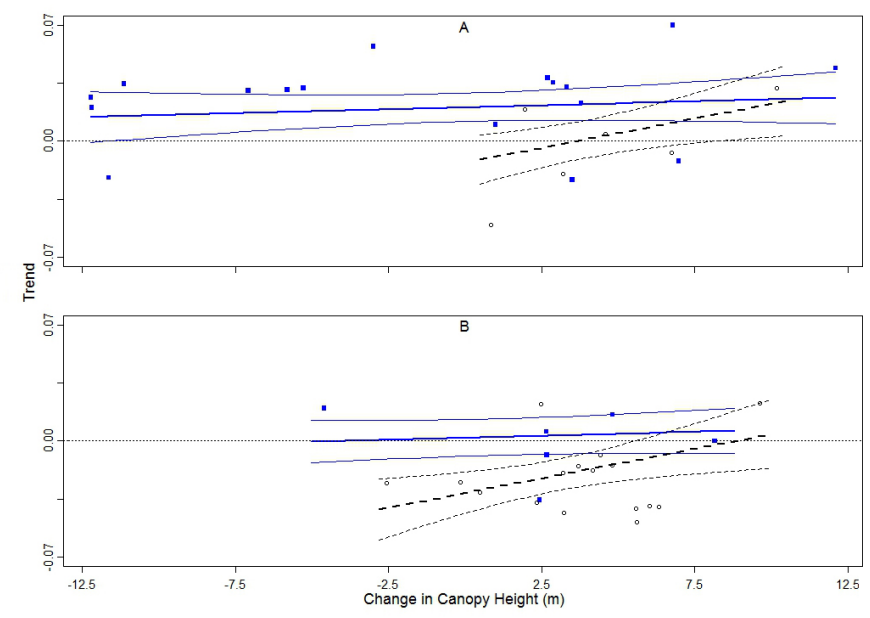

Relationships between within-stand trends in bird abundance and stand-level variables generally fit our a priori hypotheses, which was not surprising given the relatively well-known habitat associations of the study species. Here, species associated with closed-canopy forests (e.g., Swainson's Thrush, Yellow-rumped Warbler) decreased in abundance with increasing amounts of habitat disturbance within forest stands. Other authors have pointed to targeted forest harvesting of older stand age classes potentially resulting in regional reductions in the area of old forest and predicted concomitant changes in avian community composition (Hobson and Bayne 2000a, Cumming and Diamond 2002, Betts et al. 2007). Conversely, Red-eyed Vireo and Hermit Thrush were both positively associated with decreased forest cover, which was not entirely expected given that previous research in our study area did not find a relationship (positive or negative) between landscape fragmentation and abundance of these species (Hobson and Bayne 2000b). Disturbance was also important in describing species trends, with several species showing positive (e.g., Mourning Warbler, Magnolia Warbler) or negative (e.g., Ruby-crowned Kinglet, Ovenbird) associations with this variable. Some of the factors that we examined likely represent relatively localized stochastic events (e.g., windthrow) and thus would not be expected to cause systematic changes in abundance across the region unless these types of events had increased in frequency through time.

Trend estimates from our surveys did not correlate with regional trend estimates from the BBS. Working in the Northwest Territories, Canada, Machtans et al. (2014) also found little correlation between trends from a regional monitoring program and those derived from the BBS in adjacent regions and speculated that the lack of correlation could be because of local habitat factors, food resource pulses, or sampling coverage biases. Similarly, recent work by Handel and Sauer (2017) also found disparities between trends derived from roadside vs. off-road surveys. Our trend estimates only had a similar sign (negative vs. positive trend) for 5 of the 10 species but had overlapping $95 \%$ credible intervals with those derived from the BBS, with the magnitude of trend, regardless of direction, being greater in our study. For example, three species (Mourning Warbler, Magnolia Warbler, and Whitethroated Sparrow) that respond positively to early successional habitat created by forest fires and forest harvesting (Schieck and Song 2006) had opposite and sizeable differences in median trend estimates, with White-throated Sparrow and Mourning Warbler having nonoverlapping $95 \%$ credible intervals between the two surveys. Differences in the magnitude and direction between our study and the BBS indicate potentially important differences in survey coverage and habitat.

The generally more negative trends that we observed for closedcanopy associated species and more positive trends for species associated with successional habitats compared to the BBS may derive from differences in the disturbance being sampled by the BBS vs. those sampled in repeated surveys of our historic research sites. Within Saskatchewan's boreal forest, BBS sampling is almost exclusively conducted in the boreal transition zone, where the principal disturbance is associated with agriculture (Cumming et al. 2001, Hobson et al. 2002a); approximately $75 \%$ of the boreal transition zone has been converted from forest to agriculture (Hobson et al 2002a). Historically, only five BBS routes have ever been surveyed north of where agriculture is the dominant land use (i.e., the boreal transition zone), and those only have 3-9 yr of data. In contrast, our sampling was located north of the agricultural portion of the boreal ecozone, where the primary disturbances are associated with forest fires and forest harvesting (Van Wilgenburg and Hobson 2008, Van Wilgenburg et al. 2015). Thus, divergence in the trend estimates between our surveys and those from the BBS for the disturbance and canopy gap associated species might be related to poor representation of areas subjected to forest fire and logging within the limited BBS sampling in Saskatchewan because these disturbances are generally underrepresented by the roadside sampling frame (Van Wilgenburg et al. 2015).

Other authors have used forest resource inventory data to predict the abundance and distribution of forest birds across entire landscapes using regression modeling, and in some cases, have used this technique to predict future abundance, occurrence, or population size (e.g., Rempel et al. 2007, Mahon et al. 2014). The success of these approaches combined with the association of trends with local habitat change in our data suggest that it would be fruitful to extrapolate the observed changes in abundance to the broader population by linking time-specific estimates of predicted abundance to time-integrated habitat data. This approach should enhance the likelihood that the count indices accurately and precisely track population trajectories by linking avian abundance to habitat change at regional scales. Unfortunately, this is complicated by the availability of timeintegrated digital forest inventory data and labor-intensive GIS analyses. However, if habitat data were available by habitat type and age class, overall trends could be estimated by weighting derived indices of mean abundance in each age class proportional to total habitat area across the landscape. This would be similar 
to existing approaches for extending BBS data to strata defined by the intersections of BCR and political jurisdiction boundaries (e.g., Smith et al. 2014). Thus, we recommend that efforts be made to engage in monitoring habitat change in addition to expanded bird monitoring in the boreal forest (Machtans et al. 2014). A recent effort to compile a consistent digital forest inventory across Canada (Cumming et al. 2014) may facilitate these efforts across most of the commercial forest in Canada.

Our data lack the temporal replication to tease apart other climatic or weather-related factors that may contribute to species trends (e.g., Wilson et al. 2011). It would be fruitful to build upon historic surveys by repeating surveys to allow these other factors to be examined. Despite the current lack of temporal replication, we identified several other factors contributing to stand-level changes in abundance, in particular, changes in stand area and age class caused by within-stand disturbance by fires and forest harvesting. We were able to test more explicitly for disturbance vs. successional-related drivers of change in abundance because the historic research sites had detailed habitat covariates (from Hobson and Bayne 2000a,b,c) against which we could compare measures of stand structure and composition. Broad-scale surveys such as the BBS do not typically have detailed habitat covariates to allow such comparisons, thus highlighting a key advantage to using data from existing sources in comparisons such as we have done here. Furthermore, the current BBS sampling within Saskatchewan fails to adequately sample areas disturbed by fire and forest harvesting (Van Wilgenburg et al. 2015). Forest fire alone can result in rates of change in mature forest cover of $>2 \% / y r$ (Héon et al. 2014) in the boreal shield of Saskatchewan, and $>4 \%$ of the forest in BCR 6 (Boreal Taiga Plains) in Saskatchewan has been disturbed between 2002 and 2012 alone (Van Wilgenburg et al. 2015). Thus, data from repeating historic surveys offers the opportunity to assess changes in abundance in areas being affected by different ecological and anthropogenic factors that may or may not be well reflected within other monitoring efforts.

Following Blancher et al. (2009), we suggest that trend estimates from repeating historic surveys can be used in concert with regional BBS data and other monitoring programs such as migration monitoring (Hobson et al. 2015) to provide a weightof-evidence approach to assessing overall support for changes in species' status where sampling may otherwise be sparse. We recommend that effort be put into identifying historic studies with ancillary data that could be used to further examine the factors driving changes in avian populations. Our study highlights the insights that can be gained into local factors contributing to population change, and thus, we recommend that large-scale surveys such as those associated with bird atlases (Blancher et al. 2009) include protocols for collecting simple but repeatable habitat surveys (e.g., Bayne et al. 2010) and be appropriately stratified or randomized to enhance broader inference into the factors driving change in regional populations.

\section{Relevance to boreal bird conservation}

Conservation and management of boreal-breeding migratory birds is complex because of the need to understand the principal factors influencing populations over the full annual cycle. Regardless of factors occurring outside the breeding grounds, we demonstrate that local population changes were correlated with changes in local habitat supply similar to work by Holmes and
Sherry (2001) and Betts et al. (2007). Combined with previous work examining avian response to forest age and tree composition (Hobson and Bayne 2000a,b,c, Cumming and Diamond 2002, Bayne et al. 2010), our data provide further evidence that changes in forest age structure and stand height due to within-stand disturbances likely contributed to changes in avian abundance. Species such as Ovenbird and Swainson's Thrush, which are associated with older forest age classes, would therefore benefit from forest harvesting guidelines that favor the maintenance of stands on the landscape that are allowed to grow beyond traditional harvest rotation ages (Hobson and Bayne 2000a,b,c, Cumming and Diamond 2002, Bayne et al. 2010). Conversely, similar to previous work (Van Wilgenburg and Hobson 2008, Kardynal et al. 2009, 2011), we also showed that the abundance of Mourning Warbler and White-throated Sparrow increased where disturbance had occurred. Given the diverse habitat needs of boreal forest birds, using historic natural disturbance regimes (also called "emulation of natural disturbance"; Stockdale et al. 2016) to determine target forest age-class distributions may therefore improve upon historic even-aged forest management and benefit a broader range of species. In addition, retaining within-harvest residual patches may help to maintain the amount and spatial dispersion of mature and old-growth stands needed to support populations of species associated with older seral stages of forest ( $\sim 80 \mathrm{yr}$; Hobson and Schieck 1999, Schieck and Hobson 2000).

While forestry companies are increasingly attempting to maintain natural ranges of variation in forest age-class distributions and physical stand structure that might mitigate the effects of forest harvesting (Van Wilgenburg and Hobson 2008, Kuuluvainen and Grenfell 2012), other factors will influence the relative success of these efforts. Projections suggest that the area burned in the boreal mixedwood forests of western Canada could increase by $\sim 40-61 \%$ and result in a shift toward younger forest age-class distributions (Krawchuk et al. 2009, Krawchuk and Cumming 2011). Furthermore, projected climatic changes are in addition to potential management conflicts that could result from an increasing number of land uses occurring on the same land base (Aumann et al. 2007, Mahon et al. 2014). Thus, attempts to maintain or conserve forest bird populations via habitat management could face increasing constraints before any consideration of factors occurring on the wintering grounds or on migration (Sillett et al. 2000, Sillett and Holmes 2002, Faaborg et al. 2010). Long-term conservation planning for boreal forest birds should integrate land-use (e.g., Mahon et al. 2014) and climate effects occurring throughout the annual migratory cycle (Sheehy et al. 2010), as well as into the future under projected climate (e.g., Hannah et al. 2007, Carroll et al. 2009, Shaw et al. 2012).

Responses to this article can be read online at: http://www.ace-eco.org/issues/responses.php/1145

\section{Acknowledgments:}

We thank Parks Canada Agency and its staff ( S. Cherry, N. Stolle, and $H$. McPhee) for providing a scientific permit to conduct work within Prince Albert National Park (PA-2014-15976) and 
providing accommodations. Simon Allard digitized original pointcount locations from historic forest inventory maps and location descriptions. Gillian Turney assisted in Landsat classification. We thank A. Smith for kindly providing BBS trend estimates for the 1994-2014 time period. We thank E. Cumming, M. Frey, K. Konze, $B$. Korol, and R. Wapple for assistance in conducting bird surveys, and M. Smith, L. Quinette-Abbot, and T. Loran for assistance with vegetation surveys. This manuscript benefited from comments by $R$. Norris, C. Francis, and two anonymous reviewers. This work was supported by Environment Canada operating grants to $S$. Van Wilgenburg and K. Hobson, in addition to funding for work in the 1990s from Prince Albert Model Forest (Project 211) and a federalSaskatchewan Partnership Agreement in Forestry (Project \#CS5006). We thank the Terrestrial Unit of the Wildlife \& Habitat Assessment Section (PR) of Environment \& Climate Canada for additional logistical support and fruitful discussions (S. Song) that contributed to the direction of this work.

\section{LITERATURE CITED}

Acton, D. F., G. A. Padbury, and C. T. Stushnoff. 1998. The Ecoregions of Saskatchewan. Canadian Plains Research Centre, University of Regina Press, Regina, Canada.

Anderson, D. R. 2008. Model based inference in the life sciences: a primer on evidence. Springer, New York, New York, USA. http:// dx.doi.org/10.1007/978-0-387-74075-1

Arnold, T. W. 2010. Uninformative parameters and model selection using Akaike's Information Criterion. Journal of Wildlife Management 74:1175-1178. http://dx.doi.org/10.1111/ j.1937-2817.2010.tb01236.x

Aumann, C., D. R. Farr, and S. Boutin. 2007. Multiple use, overlapping tenures, and the challenge of sustainable forestry in Alberta. Forestry Chronicle 83:642-650. https://doi.org/10.5558/ tfc83642-5

Ball, G. H., and D. J. Hall. 1965. A novel method of data analysis and pattern classification. Stanford Research Institute, Menlo Park, California, USA.

Bayne, E. M., S. Haché, and K. A. Hobson. 2010. Comparing the predictive capability of forest songbird habitat models based on remotely sensed versus ground-based vegetation information. Canadian Journal of Forest Research 40:65-71. http://dx.doi. org/10.1139/X09-170

Betts, M. G., D. Mitchell, A. W. Diamond, and J. Bety. 2007. Uneven rates of landscape change as a source of bias in roadside wildlife surveys. Journal of Wildlife Management 71:2266-2273. http://dx.doi.org/10.2193/2006-004

Blancher, P. J. 2003. The importance of Canada's boreal forest to landbirds. Canadian Boreal Initiative and the Boreal Songbird Initiative, Ottawa, Canada. [online] URL: https://www. borealbirds.org/sites/default/files/publications/blancher_report_FINAL. pdf

Blancher, P. J., R. D. Phoenix, D. S. Badzinski, M. D. Cadman, T. L. Crewe, C. M. Downes, D. Fillman, C. M. Francis, J. Hughes, D. J. T. Hussell, D. Lepage, J. D. McCracken, N. K. McNicol, B. A. Pond, R. K. Ross, R. Russell, L. A. Venier, and R. C. Weeber.
2009. Population trend status of Ontario's forest birds. Forestry Chronicle 85:184-201. http://dx.doi.org/10.5558/tfc85184-2

Burnham, K. P., and D. R. Anderson. 2002. Model selection and multimodel inference: a practical information-theoretic approach. Springer-Verlag, New York, New York, USA. http://dx.doi. org/10.1007/b97636

Butcher, G. S., M. R. Fuller, L. S. McAllister, and P. H. Geissler. 1990. An evaluation of the Christmas Bird Count for monitoring population trends of selected species. Wildlife Society Bulletin 18:129-134. [online] URL: http://www.jstor.org/stable/3782126

Cade, B. S. 2015. Model averaging and muddled multimodel inferences. Ecology 96:2370-2382. http://dx.doi.org/10.1890/14-1639.1

Calvert, A. M., C. A. Bishop, R. D. Elliot, E. A. Krebs, T. M. Kydd, C. S. Machtans, and G. J. Robertson. 2013. A synthesis of human-related avian mortality in Canada. Avian Conservation and Ecology 8(2):11. http://dx.doi.org/10.5751/ACE-00581-080211

Carroll, C., J. R. Dunk, and A. Moilanen. 2009. Optimizing resiliency of reserve networks to climate change: multispecies conservation planning in the Pacific Northwest, USA. Global Change Biology 16:891-904. http://dx.doi.org/10.1111/

j.1365-2486.2009.01965.x

Cumming, E. E., and A. W. Diamond. 2002. Songbird community composition versus forest rotation age in Saskatchewan boreal mixedwood forest. Canadian Field-Naturalist 116:69-75.

Cumming, E. E., K. A. Hobson, and S. L. Van Wilgenburg. 2001. Breeding bird declines in the boreal forest fringe of western Canada: insights from long-term BBS routes. Canadian FieldNaturalist 115:425-435.

Cumming, S. G., C. R. Drever, M. Houle, J. Cosco, P. Racine, E. Bayne, and F. K. A. Schmiegelow. 2014. A gap analysis of tree species representation in the protected areas of the Canadian boreal forest: applying a new assemblage of digital Forest Resource Inventory data. Canadian Journal of Forest Research 45:163-173. http://dx.doi.org/10.1139/cjfr-2014-0102

Dunn, E. H., B. L. Altman, J. Bart, C. J. Beardmore, H. Berlanga, P. J. Blancher, G. S. Butcher, D. W. Demarest, R. Dettmers, W. C. Hunter, E. E. Iñigo-Elias, A. O. Panjabi, D. N. Pashley, C. J. Ralph, T. D. Rich, K. V. Rosenberg, C. M. Rustay, J. M. Ruth, and T. C. Will. 2005. High priority needs for range-wide monitoring of North American landbirds. Partners in Flight Technical Series 2. Partners in Flight, Laurel, Maryland, USA. [online] URL: https://pubs.er. usgs.gov/publication/2002817

Faaborg, J., R. T. Holmes, A. D. Anders, K. L. Bildstein, K. M. Dugger, S. A. Gauthreaux Jr., P. Heglund, K. A. Hobson, A. E. Jahn, D. H. Johnson, S. C. Latta, D. J. Levey, P. P. Marra, C. L. Merkord, E. Nol, S. I. Rothstein, T. W. Sherry, S. Sillett, F. R. Thompson III, and N. Warnock. 2010. Conserving migratory landbirds in the New World: Do we know enough? Ecological Applications 20:398-418. http://dx.doi.org/10.1890/09-0397.1

Fournier, D. A., H. J. Skaug, J. Ancheta, J. Ianelli, A. Magnusson, M. N. Maunder, A. Nielsen, and J. Sibert. 2012. AD model builder: using automatic differentiation for statistical inference of highly parameterized complex nonlinear models. Optimization 
Methods Software 27:233-249. http://dx.doi.org/10.1080/10556788.2011.597854

Freckleton, R. P. 2011. Dealing with collinearity in behavioural and ecological data: model averaging and the problems of measurement error. Behavioral Ecology and Sociobiology 65:91-101. http://dx.doi.org/10.1007/s00265-010-1045-6

Handel, C. M., and J. R. Sauer. 2017. Combined analysis of roadside and off-road breeding bird survey data to assess population change in Alaska. Condor 119:557-575. http://dx.doi. org/10.1650/CONDOR-17-67.1

Hannah, L., G. Midgley, S. Andelman, M. Araújo, G. Hughes, E. Martinez-Meyer, R. Pearson, and P. Williams. 2007. Protected area needs in a changing climate. Frontiers in Ecology and the Environment 5:131-138. http://dx.doi.org/10.1890/1540-9295 (2007)5[131:PANIAC]2.0.CO;2

Héon, J., D. Arseneault, and M. A. Parisien. 2014. Resistance of the boreal forest to high burn rates. Proceedings of the National Academy of Sciences 111:13888-13893. http://dx.doi.org/10.1073/ pnas. 1409316111

Hobson, K. A., and E. Bayne. 2000a. The effects of stand age on avian communities in aspen-dominated forests of central Saskatchewan, Canada. Forest Ecology and Management 136:121-134. https://doi.org/10.1016/S0378-1127(99)00287-X

Hobson, K. A., and E. M. Bayne. 2000b. Effects of forest fragmentation by agriculture on avian communities in the southern boreal mixedwoods of western Canada. Wilson Bulletin 112:373-387. https://doi.org/10.1676/0043-5643(2000)112[0373: EOFFBA]2.0.CO;2

Hobson, K. A., and E. M. Bayne. 2000c. Breeding bird communities in boreal forest of western Canada: consequences of "unmixing" the mixedwoods. Condor 102:759-769. https://doi. org/10.1650/0010-5422(2000)102[0759:BBCIBF]2.0.CO;2

Hobson, K. A., E. M. Bayne, and S. L. Van Wilgenburg. $2002 a$. Large-scale conversion of forest to agriculture in the boreal plains of Saskatchewan. Conservation Biology 16:1530-1541. http://dx. doi.org/10.1046/j.1523-1739.2002.01199.x

Hobson, K. A., R. S. Rempel, H. Greenwood, B. Turnbull, and S. L. Van Wilgenburg. 2002b. Acoustic surveys of birds using electronic recordings: new potential from an omnidirectional microphone system. Wildlife Society Bulletin 30:709-720. [online] URL: http://www.jstor.org/stable/3784223

Hobson, K. A., and J. Schieck. 1999. Changes in bird communities in boreal mixedwood forest: harvest and wildfire effects over 30 years. Ecological Applications 9:849-863. http://dx.doi. org/10.1890/1051-0761(1999)009[0849:CIBCIB]2.0.CO;2

Hobson, K. A., S. L. Van Wilgenburg, E. H. Dunn, D. J. T. Hussell, P. D. Taylor, and D. M. Collister. 2015. Predicting origins of passerines migrating through Canadian migration monitoring stations using stable-hydrogen isotope analyses of feathers: a new tool for bird conservation. Avian Conservation and Ecology 10 (1):3. http://dx.doi.org/10.5751/ACE-00719-100103

Holmes, R. T., and T. W. Sherry. 2001. Thirty-year bird population trends in an unfragmented temperate deciduous forest: importance of habitat change. Auk 118:589-609. [online] URL: http://www.jstor.org/stable/4089923

Hoover, J. 2012. GIS collaborations in Saskatchewan: SGIC and the University of Saskatchewan Library. Journal of Map and Geography Libraries 8:68-79. http://dx.doi.org/10.1080/15420353.2011.622601

Hudson, M.-A. R., C. M. Francis, K. J. Campbell, C. M. Downes, A. C. Smith, and K. L. Pardieck. 2017. The role of the North American Breeding Bird Survey in conservation. Condor 119:526-545. http://dx.doi.org/10.1650/CONDOR-17-62.1

Kardynal, K. J., K. A. Hobson, S. L. Van Wilgenburg, and J. L. Morissette. 2009. Moving riparian management guidelines towards a natural disturbance model: an example using boreal riparian and shoreline forest bird communities. Forest Ecology and Management 257:54-65. http://dx.doi.org/10.1016/j. foreco.2008.08.029

Kardynal, K. J., J. L. Morissette, S. L. Van Wilgenburg, E. M. Bayne, and K. A. Hobson. 2011. Avian responses to experimental harvest in southern boreal mixedwood shoreline forests: implications for riparian buffer management. Canadian Journal of Forest Research 41:2375-2388. http://dx.doi.org/10.1139/ $\mathrm{x} 11-145$

Kirk, D. A., A. W. Diamond, A. R. Smith, G. E. Holland, and P. Chytyk. 1997. Population changes in boreal forest birds in Saskatchewan and Manitoba. Wilson Bulletin 109:1-27. [online] URL: http://www.jstor.org/stable/4163771

Kirk, D. A., and K. A. Hobson. 2001. Bird-habitat relationships in jack pine boreal forests. Forest Ecology and Management 147:217-243. http://dx.doi.org/10.1016/S0378-1127(00)00465-5

Krawchuk, M. A., and S. G. Cumming. 2011. Effects of biotic feedback and harvest management on boreal forest fire activity under climate change. Ecological Applications 21:122-136. http:// dx.doi.org/10.1890/09-2004.1

Krawchuk, M. A., S. G. Cumming, and M. D. Flannigan. 2009. Predicted changes in fire weather suggest increases in lightning fire initiation and future area burned in the mixedwood boreal forest. Climatic Change 92:83-97. http://dx.doi.org/10.1007/ s10584-008-9460-7

Kuuluvainen, T., and R. Grenfell, R. 2012. Natural disturbance emulation in boreal forest ecosystem management-theories, strategies, and a comparison with conventional even-aged management. Canadian Journal of Forest Research 42:1185-1203. https://doi.org/10.1139/x2012-064

Machtans, C. S., K. J. Kardynal, and P. A. Smith. 2014. How well do regional or national Breeding Bird Survey data predict songbird population trends at an intact boreal site? Avian Conservation and Ecology 9(1):5. http://dx.doi.org/10.5751/ ACE-00649-090105

Machtans, C. S., S. L. Van Wilgenburg, L. A. Armer, and K. A Hobson 2007. Retrospective comparison of the occurrence and abundance of Rusty Blackbird in the Mackenzie Valley, Northwest Territories. Avian Conservation and Ecology 2(1):3. http://dx.doi.org/10.5751/ACE-00106-020103 
Mahon, C. L., E. M. Bayne, P. Sólymos, S. M. Matsuoka, M. Carlson, E. Dzus, F. K. A. Schmiegelow, and S. J. Song. 2014. Does expected future landscape condition support proposed population objectives for boreal birds? Forest Ecology and Management 312:28-39. https://doi.org/10.1016/j.foreco.2013.10.025

Matsuoka, S. M., E. M. Bayne, P. Sólymos, P. C. Fontaine, S. G. Cumming, F. K. A. Schmiegelow, and S. J. Song. 2012. Using binomial distance-sampling models to estimate the effective detection radius of point-count surveys across Boreal Canada. Auk 129:268-282. http://dx.doi.org/10.1525/auk.2012.11190

Matsuoka, S. M., C. L. Mahon, C. M. Handel, P. Sólymos, E. M. Bayne, P. C. Fontaine, and C. J. Ralph. 2014. Reviving common standards in point-count surveys for broad inference across studies. Condor 116:599-608. http://dx.doi.org/10.1650/

CONDOR-14-108.1

Matsuoka, S., P. Solymos, T. Fontaine, E. Bayne. 2011. Roadside surveys of boreal forest birds: how representative are they and how can we improve current sampling? Report to Environment Canada, Canadian Wildlife Service, Edmonton, Canada.

Mazerolle, M. J. 2014. AICcmodavg: model selection and multimodel inference based on $(Q) A I C(c)$. R version 2.00. [online] URL: http://CRAN.R-project.org/package=AICcmodavg

Poole, A., editor. 2005. The birds of North America. Cornell Laboratory of Ornithology, Ithaca, New York, USA. [online] URL: http://bna.birds.cornell.edu/bna/

R Core Team. 2014. R: a language and environment for statistical computing. R Foundation for Statistical Computing, Vienna, Austria. [online] URL: http://www.R-project.org/

Rempel, R. S., J. Baker, P. C. Elkie, M. J. Gluck, J. Jackson, R. S. Kushneriuk, T. Moore, and A. H. Perera. 2007. Forest policy scenario analysis: sensitivity of songbird community to changes in forest cover amount and configuration. Avian Conservation and Ecology 2(1):5. http://dx.doi.org/10.5751/ACE-00139-020105

Royle, J. A., and R. M. Dorazio. 2006. Hierarchical models of animal abundance and occurrence. Journal of Agricultural Biological and Environmental Statistics 11:249-263. http://dx.doi. org/10.1198/108571106X129153

Schieck, J., and K. A. Hobson. 2000. Bird communities associated with live residual tree patches within cut blocks and burned habitat in mixedwood boreal forests. Canadian Journal of Forest Research 30(8):1281-1295. https://doi.org/10.1139/x00-061

Schieck, J., and S. J. Song. 2006. Changes in bird communities throughout succession following fire and harvest in boreal forests of western North America: literature review and meta-analyses. Canadian Journal of Forest Research 36:1299-1318. http://dx.doi. org/10.1139/x06-017

Schmiegelow, F. K. A, and M. Mönkkönen. 2002. Habitat loss and fragmentation in dynamic landscapes: avian perspectives from the boreal forest. Ecological Applications 12:375-389. http:// dx.doi.org/10.1890/1051-0761(2002)012[0375:HLAFID]2.0.CO;2

Shaw, M. R., K. Klausmeyer, D. R. Cameron, J. MacKenzie, and P. Roehrdanz. 2012. Economic costs of achieving current conservation goals in the future as climate changes. Conservation Biology 26:385-396. http://dx.doi.org/10.1111/j.1523-1739.2012.01824. $\mathrm{x}$
Sheehy, J., C. M. Taylor, K. S. McCann, and D. R. Norris. 2010. Optimal conservation planning for migratory animals: integrating demographic information across seasons. Conservation Letters 3:192-202. http://dx.doi.org/10.1111/j.1755-263X.2010.00100. $\mathrm{x}$

Sillett, T. S., and R. T. Holmes. 2002. Variation in survivorship of a migratory songbird throughout its annual cycle. Journal of Animal Ecology 71:296-308. http://dx.doi.org/10.1046/ j.1365-2656.2002.00599.x

Sillett, T. S., R. T. Holmes, and T. W. Sherry. 2000. Impacts of a global climate cycle on population dynamics of a migratory songbird. Science 288:2040-2042. http://dx.doi.org/10.1126/ science. 288.5473 .2040

Skaug, H., D. Fournier, B. Bolker, A. Magnusson, and A. Nielsen. 2015. Generalized linear mixed models using 'AD model builder.' $\mathrm{R}$ version 0.8.1. [online] URL: https://rdrr.io/rforge/glmmADMB/

Smith, A. C., M. A. R. Hudson, C. Downes, and C. M. Francis. 2014. Estimating breeding bird survey trends and annual indices for Canada: How do the new hierarchical Bayesian estimates differ from previous estimates? Canadian Field-Naturalist 128:119-134. http://dx.doi.org/10.22621/cfn.v128i2.1565

Stockdale, C., M. Flannigan, and E. Macdonald. 2016. Is the END (emulation of natural disturbance) a new beginning? A critical analysis of the use of fire regimes as the basis of forest ecosystem management with examples from the Canadian western Cordillera. Environmental Reviews 24:233-243. http://dx. doi.org/10.1139/er-2016-0002

Stralberg, D., S. M. Matsuoka, A. Hamann, E. M. Bayne, P. Sólymos, F. K. A. Schmiegelow, X. Wang, S. G. Cumming, and S. J. Song 2015. Projecting boreal bird responses to climate change: the signal exceeds the noise. Ecological Applications 25: 52-69. http://dx.doi.org/10.1890/13-2289.1

Toms, J. D., F. K. A. Schmiegelow, S. J. Hannon, and M. A. Villard. 2006. Are point counts of boreal songbirds reliable proxies for more intensive abundance estimators? Auk 123:438-454. https://doi.org/10.1642/0004-8038(2006)123[438: APCOBS]2.0.CO;2

Van Wilgenburg, S. L., E. M. Beck, B. Obermayer, T. Joyce, and B. Weddle. 2015. Biased representation of disturbance rates in the roadside sampling frame in boreal forests: implications for monitoring design. Avian Conservation and Ecology 10(2):5. http://dx.doi.org/10.5751/ACE-00777-100205

Van Wilgenburg, S. L., and K. A. Hobson. 2008. Landscape-scale disturbance and boreal forest birds: Can large single-pass harvest approximate fires? Forest Ecology and Management 256:136-146. https://doi.org/10.1016/j.foreco.2008.04.017

Wells, J. V. editor. 2011. Boreal birds of North America: a hemispheric view of their conservation links and significance. University of California Press, Oakland, California, USA.

Wilson, S., S. L. LaDeau, A. P. Tøttrup, and P. P. Marra. 2011. Range-wide effects of breeding- and nonbreeding-season climate on the abundance of a Neotropical migrant songbird. Ecology 92:1789-1798. http://dx.doi.org/10.1890/10-1757.1 
Avian Conservation and Ecology 13(1): 3 http://www.ace-eco.org/vol13/iss1/art3/

Zuur, A. F., E. N. Ieno, N. J. Walker, A. Saveliev, and G. M. Smith. 2009. Mixed effects models and extensions in ecology with $R$. Springer, New York, New York, USA. http://dx.doi. org/10.1007/978-0-387-87458-6 
Appendix 1. Initial candidate models and model selection statistics for models examining variation in stand-level trends (between circa 1994 and 2014) in abundance for ten species of passerine in aspen dominated mixedwood forests in central Saskatchewan.

Table A1.1 Information theoretic based model selection for models examining variation in standlevel trends (between circa 1994 and 2014) in abundance for ten species of passerine in aspen dominated mixedwood forests in central Saskatchewan. $K$ denotes the number of estimated parameters in the model, AIC $c$ denotes Akaike's Information Criterion with second-order bias correction, $\triangle \mathrm{AIC} c$ is the difference in $\mathrm{AIC} c$ between the given model and the model with the lowest $\mathrm{AIC} c$ value, and $w_{i}$ refers to the $\mathrm{AIC} c$ weight.

\begin{tabular}{lccccc}
\hline \hline Model name & $K$ & Log-Likelihood & $\mathrm{AIC} c$ & $\Delta \mathrm{AIC} c$ & $w_{\mathrm{i}}$ \\
\hline Red-eyed Vireo & & & & & \\
Proportion Disturbed & 3 & 113.77 & -220.93 & 0.00 & 0.33 \\
Windthrow & 4 & 114.14 & -219.26 & 1.67 & 0.14 \\
Stand Age & 4 & 114.06 & -219.09 & 1.84 & 0.13 \\
Protected Areas & 4 & 114.02 & -219.02 & 1.91 & 0.13 \\
Change in Height & 4 & 114.01 & -219.00 & 1.93 & 0.13 \\
Change in Percent Conifer & 4 & 113.90 & -218.78 & 2.15 & 0.11 \\
Null & 2 & 109.71 & -215.12 & 5.81 & 0.02 \\
& & & & & \\
Ruby-crowned Kinglet & & & & & \\
Change in Height & 4 & 129.06 & -249.09 & 0.00 & 0.68 \\
Null & 2 & 124.66 & -245.03 & 4.06 & 0.09 \\
Proportion Disturbed & 3 & 125.78 & -244.95 & 4.14 & 0.09 \\
Protected Areas & 4 & 126.61 & -244.19 & 4.90 & 0.06 \\
Stand Age & 4 & 126.05 & -243.07 & 6.02 & 0.03 \\
Change in Percent Conifer & 4 & 125.86 & -242.69 & 6.40 & 0.03 \\
Windthrow & 4 & 125.83 & -242.64 & 6.45 & 0.03 \\
& & & & & \\
Swainson's Thrush & & & & & \\
Proportion Disturbed & 3 & 165.62 & -324.64 & 0.00 & 0.35 \\
Change in Height & 4 & 166.12 & -323.22 & 1.43 & 0.17 \\
Windthrow & 4 & 165.97 & -322.92 & 1.73 & 0.15 \\
Protected Areas & 4 & 165.75 & -322.47 & 2.18 & 0.12 \\
Change in Percent Conifer & 4 & 165.67 & -322.31 & 2.33 & 0.11 \\
Stand Age & 4 & 165.63 & -322.23 & 2.42 & 0.10 \\
Null & 2 & 160.35 & -316.40 & 8.25 & 0.01
\end{tabular}

Hermit Thrush 


$\begin{array}{llllll}\text { Windthrow } & 4 & 111.13 & -213.23 & 0.00 & 0.28 \\ \text { Proportion Disturbed } & 3 & 109.88 & -213.16 & 0.07 & 0.27 \\ \text { Stand Age } & 4 & 110.34 & -211.65 & 1.58 & 0.13 \\ \text { Change in Percent Conifer } & 4 & 109.95 & -210.88 & 2.35 & 0.09 \\ \text { Change in Height } & 4 & 109.90 & -210.77 & 2.46 & 0.08 \\ \text { Protected Areas } & 4 & 109.88 & -210.73 & 2.50 & 0.08 \\ \text { Null } & 2 & 107.38 & -210.47 & 2.76 & 0.07\end{array}$

\section{Ovenbird}

Windthrow

Stand Age

Proportion Disturbed

Change in Height

Change in Percent Conifer

Protected Areas

Null

$\begin{array}{lllll}4 & 94.24 & -179.46 & 0.00 & 0.44 \\ 4 & 93.80 & -178.57 & 0.89 & 0.28 \\ 3 & 91.78 & -176.97 & 2.50 & 0.13 \\ 4 & 92.29 & -175.56 & 3.90 & 0.06 \\ 4 & 91.90 & -174.77 & 4.69 & 0.04 \\ 4 & 91.78 & -174.54 & 4.92 & 0.04 \\ 2 & 85.73 & -167.17 & 12.30 & 0.00\end{array}$

Mourning Warbler

Windthrow

Stand Age

Proportion Disturbed

Null

Change in Percent Conifer

Protected Areas

Change in Height

$\begin{array}{lllll}4 & 111.78 & -214.53 & 0.00 & 0.35 \\ 4 & 111.64 & -214.25 & 0.28 & 0.30 \\ 3 & 109.42 & -212.25 & 2.28 & 0.11 \\ 2 & 107.97 & -211.64 & 2.89 & 0.08 \\ 4 & 110.17 & -211.31 & 3.22 & 0.07 \\ 4 & 109.90 & -210.78 & 3.75 & 0.05 \\ 4 & 109.56 & -210.10 & 4.43 & 0.04\end{array}$

Magnolia Warbler

Conifer Cover + Windthrow

Stand Age

$\begin{array}{llll}112.74 & -216.44 & 0.00 & 0.30\end{array}$

Windthrow

110.98

$\begin{array}{lll}-215.36 & 1.09 & 0.18\end{array}$

Change in Conifer Cover

110.98

$-215.35$

$1.09 \quad 0.18$

Conifer Cover + Stand Age 4

110.62

$-214.64$

$1.80 \quad 0.12$

Null

111.79

$-214.56$

$1.89 \quad 0.12$

$\begin{array}{llll}108.55 & -212.81 & 3.64 & 0.05\end{array}$

Change in height

109.33

$\begin{array}{lll}-212.05 & 4.39 & 0.03\end{array}$

Protected Areas

108.68

$\begin{array}{lll}-210.75 & 5.69 & 0.02\end{array}$

Yellow-rumped Warbler

$\begin{array}{llllll}\text { Change in Percent Conifer } & 4 & 188.79 & -368.56 & 0.00 & 0.29\end{array}$

Proportion Disturbed

187.48

$\begin{array}{lll}-368.35 & 0.21 & 0.26\end{array}$ 


\begin{tabular}{llllll} 
Windthrow & 4 & 188.17 & -367.31 & 1.25 & 0.16 \\
Change in Height & 4 & 187.78 & -366.54 & 2.02 & 0.11 \\
Stand Age & 4 & 187.48 & -365.94 & 2.62 & 0.08 \\
Protected Areas & 4 & 187.48 & -365.93 & 2.64 & 0.08 \\
Null & 2 & 184.07 & -363.84 & 4.72 & 0.03 \\
& & & & & \\
Chipping Sparrow & & & & & \\
Change in Height & 4 & 152.79 & -296.56 & 0.00 & 0.37 \\
Proportion Disturbed & 3 & 150.87 & -295.14 & 1.43 & 0.18 \\
Stand Age & 4 & 152.05 & -295.08 & 1.48 & 0.18 \\
Change in Percent Conifer & 4 & 151.74 & -294.45 & 2.11 & 0.13 \\
Protected Areas & 4 & 151.17 & -293.31 & 3.25 & 0.07 \\
Windthrow & 4 & 150.99 & -292.96 & 3.61 & 0.06 \\
Null & 2 & 145.76 & -287.22 & 9.34 & 0.00 \\
& & & & & \\
White-throated Sparrow & & & & & \\
Conifer Cover + Stand Age & 4 & 101.79 & -194.55 & 0.00 & 0.63 \\
Stand Age & 3 & 99.95 & -193.31 & 1.24 & 0.34 \\
Change in Conifer Cover & 3 & 97.06 & -187.52 & 7.04 & 0.02 \\
Conifer Cover + Windthrow & 4 & 97.93 & -186.84 & 7.71 & 0.01 \\
Windthrow & 3 & 93.40 & -180.21 & 14.34 & 0.00 \\
Null & 2 & 92.21 & -180.13 & 14.43 & 0.00 \\
Change in height & 3 & 92.62 & -178.64 & 15.91 & 0.00 \\
Protected Areas & 3 & 92.21 & -177.82 & 16.73 & 0.00 \\
\hline
\end{tabular}


Appendix 2. Parameter estimates for models examining variation in stand-level trends (between circa 1994 and 2014) in abundance for ten species of passerine in aspen dominated mixedwood forests of central Saskatchewan.

Table A2.1 Parameter estimates for models examining variation in stand-level trends (between circa 1994 and 2014) in abundance Red-eyed Vireo in aspen dominated mixedwood forests in central Saskatchewan. 85\% Confidence Intervals can be obtained as $\beta \pm 1.44 *$ SE. NOTE:

Parameter values were rescaled by multiplying with a constant (100) for ease of presentation, divide by 100 to obtain estimates.

\begin{tabular}{|c|c|c|c|c|c|c|c|c|c|c|c|c|c|c|c|c|c|c|}
\hline \multirow[b]{2}{*}{ Model } & \multicolumn{2}{|c|}{ Intercept } & \multicolumn{2}{|c|}{$\mathrm{PD}^{\dagger}$} & \multicolumn{2}{|c|}{$\triangle \mathrm{PC}$} & \multicolumn{2}{|c|}{ Stand age } & \multicolumn{2}{|c|}{ Windthrow } & \multicolumn{2}{|c|}{ Park } & \multicolumn{2}{|c|}{$\overline{\mathrm{c} \Delta \mathrm{Ht}}$} & \multicolumn{2}{|c|}{ Dist. } & \multicolumn{2}{|c|}{ 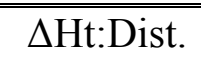 } \\
\hline & $\beta$ & SE & $\beta$ & SE & $\beta$ & SE & $\beta$ & SE & $\beta$ & SE & $\beta$ & SE & $\beta$ & SE & $\beta$ & SE & $\beta$ & SE \\
\hline 1 & -0.03 & 0.22 & & & & & & & & & & & & & & & & \\
\hline 2 & 0.18 & 0.25 & 1.13 & 0.72 & & & & & & & & & & & & & & \\
\hline 3 & 0.07 & 0.31 & 1.27 & 0.77 & & & 0.26 & 0.45 & & & & & & & & & & \\
\hline 4 & 0.17 & 0.27 & 0.94 & 0.78 & 0.00 & 0.01 & & & & & & & & & & & & \\
\hline 5 & -0.01 & 0.48 & -1.96 & 1.24 & & & & & & & & & 0.04 & 0.10 & -0.78 & 0.63 & 0.16 & 0.12 \\
\hline 6 & 0.44 & 0.34 & 1.50 & 0.78 & & & & & & & -0.56 & 0.49 & & & & & & \\
\hline 7 & 0.12 & 0.29 & 1.06 & 0.75 & & & & & 0.21 & 0.55 & & & & & & & & \\
\hline
\end{tabular}

$\uparrow$ Note that negative parameter values imply a positive relationship due to negative covariate values representing decrease in stand area 
Table A2.2 Parameter estimates for models examining variation in stand-level trends (between circa 1994 and 2014) in abundance Rubycrowned Kinglet in aspen dominated mixedwood forests in central Saskatchewan. 85\% Confidence Intervals can be obtained as $\beta \pm 1.44 *$ SE. NOTE: Parameter values were rescaled by multiplying with a constant (100) for ease of presentation, divide by 100 to obtain estimates.

\begin{tabular}{|c|c|c|c|c|c|c|c|c|c|c|c|c|c|c|c|c|c|c|}
\hline \multirow[b]{2}{*}{ Model } & \multicolumn{2}{|c|}{ Intercept } & \multicolumn{2}{|c|}{$\mathrm{PD}^{\dagger}$} & \multicolumn{2}{|c|}{$\Delta \mathrm{PC}$} & \multicolumn{2}{|c|}{ Stand age } & \multicolumn{2}{|c|}{ Windthrow } & \multicolumn{2}{|c|}{ Park } & \multicolumn{2}{|c|}{$\Delta \mathrm{Ht}$} & \multicolumn{2}{|c|}{ Dist. } & \multicolumn{2}{|c|}{$\Delta \mathrm{Ht}$ :Dist. } \\
\hline & $\beta$ & $\mathrm{SE}$ & $\beta$ & SE & $\beta$ & SE & $\beta$ & SE & $\beta$ & $\mathrm{SE}$ & $\beta$ & SE & $\beta$ & $\mathrm{SE}$ & $\beta$ & $\mathrm{SE}$ & $\beta$ & SE \\
\hline 1 & -0.03 & 0.22 & & & & & & & & & & & & & & & & \\
\hline 2 & 0.18 & 0.25 & 1.13 & 0.72 & & & & & & & & & & & & & & \\
\hline 3 & 0.07 & 0.31 & 1.27 & 0.77 & & & 0.26 & 0.45 & & & & & & & & & & \\
\hline 4 & 0.17 & 0.27 & 0.94 & 0.78 & 0.00 & 0.01 & & & & & & & & & & & & \\
\hline 5 & -0.01 & 0.48 & -1.96 & 1.24 & & & & & & & & & 0.04 & 0.10 & -0.78 & 0.63 & 0.16 & 0.12 \\
\hline 6 & 0.44 & 0.34 & 1.50 & 0.78 & & & & & & & -0.56 & 0.49 & & & & & & \\
\hline 7 & 0.12 & 0.29 & 1.06 & 0.75 & & & & & 0.21 & 0.55 & & & & & & & & \\
\hline
\end{tabular}

$\uparrow$ Note that negative parameter values imply a positive relationship due to negative covariate values representing decrease in stand area

Table A2.3 Parameter estimates for models examining variation in stand-level trends (between circa 1994 and 2014) in abundance Swainson's Thrush in aspen dominated mixedwood forests in central Saskatchewan. $85 \%$ Confidence Intervals can be obtained as $\beta \pm 1.44 *$ SE. NOTE: Parameter values were rescaled by multiplying with a constant (100) for ease of presentation, divide by 100 to obtain estimates.

\begin{tabular}{|c|c|c|c|c|c|c|c|c|c|c|c|c|c|c|c|c|c|c|}
\hline \multirow[b]{2}{*}{ Model } & \multicolumn{2}{|c|}{ Intercept } & \multicolumn{2}{|c|}{$\mathrm{PD}^{\dagger}$} & \multicolumn{2}{|c|}{$\triangle \mathrm{PC}$} & \multicolumn{2}{|c|}{ Stand age } & \multicolumn{2}{|c|}{ Windthrow } & \multirow{2}{*}{$\begin{array}{c}\text { Park } \\
\beta\end{array}$} & \multicolumn{3}{|c|}{$\Delta \mathrm{Ht}$} & \multicolumn{2}{|c|}{ Dist. } & \multicolumn{2}{|c|}{$\Delta \mathrm{Ht}:$ Dist. } \\
\hline & $\beta$ & $\mathrm{SE}$ & $\beta$ & $\mathrm{SE}$ & $\beta$ & SE & $\beta$ & SE & $\beta$ & $\mathrm{SE}$ & & SE & $\beta$ & $\mathrm{SE}$ & $\beta$ & SE & $\beta$ & SE \\
\hline 1 & 0.09 & 0.10 & & & & & & & & & & & & & & & & \\
\hline 2 & 0.26 & 0.10 & 1.00 & 0.29 & & & & & & & & & & & & & & \\
\hline 3 & 0.28 & 0.13 & 0.98 & 0.31 & & & -0.03 & 0.18 & & & & & & & & & & \\
\hline 4 & 0.26 & 0.11 & 0.94 & 0.32 & 0.00 & 0.00 & & & & & & & & & & & & \\
\hline 5 & 0.42 & 0.21 & 1.21 & 0.54 & & & & & & & & & -0.03 & 0.04 & -0.10 & 0.28 & 0.02 & 0.05 \\
\hline 6 & 0.30 & 0.14 & 1.05 & 0.32 & & & & & & & -0.08 & 0.20 & & & & & & \\
\hline 7 & 0.22 & 0.12 & 0.93 & 0.30 & & & & & 0.19 & 0.22 & & & & & & & & \\
\hline
\end{tabular}

$\dagger$ Note that negative parameter values imply a positive relationship due to negative covariate values representing decrease in stand area 
Table A2.4 Parameter estimates for models examining variation in stand-level trends (between circa 1994 and 2014) in abundance Hermit Thrush in aspen dominated mixedwood forests in central Saskatchewan. 85\% Confidence Intervals can be obtained as $\beta \pm 1.44 *$ SE. NOTE: Parameter values were rescaled by multiplying with a constant (100) for ease of presentation, divide by 100 to obtain estimates.

\begin{tabular}{|c|c|c|c|c|c|c|c|c|c|c|c|c|c|c|c|c|c|c|}
\hline \multirow[b]{2}{*}{ Model } & \multicolumn{2}{|c|}{ Intercept } & \multicolumn{2}{|c|}{$\mathrm{PD}^{\dagger}$} & \multicolumn{2}{|c|}{$\triangle \mathrm{PC}$} & \multicolumn{2}{|c|}{ Stand age } & \multicolumn{2}{|c|}{ Windthrow } & \multicolumn{2}{|c|}{ Park } & \multicolumn{2}{|c|}{$\Delta \mathrm{Ht}$} & \multicolumn{2}{|c|}{ Dist. } & \multicolumn{2}{|c|}{$\Delta \mathrm{Ht}:$ Dist. } \\
\hline & $\beta$ & SE & $\beta$ & SE & $\beta$ & SE & $\beta$ & SE & $\beta$ & $\mathrm{SE}$ & $\beta$ & $\mathrm{SE}$ & $\beta$ & SE & $\beta$ & SE & $\beta$ & $\mathrm{SE}$ \\
\hline 1 & 0.18 & 0.32 & & & & & & & & & & & & & & & & \\
\hline 2 & -0.21 & 0.36 & -2.19 & 1.04 & & & & & & & & & & & & & & \\
\hline 3 & 0.08 & 0.45 & -2.59 & 1.10 & & & -0.71 & 0.65 & & & & & & & & & & \\
\hline 4 & -0.12 & 0.38 & -2.15 & 1.12 & & & & & & & & & & & & & & \\
\hline 5 & -0.56 & 0.74 & -1.23 & 1.91 & & & & & & & & & 0.18 & 0.15 & 0.33 & 0.97 & -0.28 & 0.18 \\
\hline 6 & -0.26 & 0.50 & -2.26 & 1.15 & & & & & & & 0.11 & 0.71 & & & & & & \\
\hline 7 & 0.08 & 0.41 & -1.18 & 1.06 & & & & & -1.13 & 0.78 & & & & & & & & \\
\hline
\end{tabular}

$\dagger$ Note that negative parameter values imply a positive relationship due to negative covariate values representing decrease in stand area

Table A2.5 Parameter estimates for models examining variation in stand-level trends (between circa 1994 and 2014) in abundance Ovenbird in aspen dominated mixedwood forests in central Saskatchewan. 85\% Confidence Intervals can be obtained as $\beta \pm 1.44 *$ SE. NOTE: Parameter values were rescaled by multiplying with a constant (100) for ease of presentation, divide by 100 to obtain estimates.

\begin{tabular}{|c|c|c|c|c|c|c|c|c|c|c|c|c|c|c|c|c|c|c|}
\hline \multirow[b]{2}{*}{ Model } & \multicolumn{2}{|c|}{ Intercept } & \multicolumn{2}{|c|}{$\mathrm{PD}^{\dagger}$} & \multicolumn{2}{|c|}{$\Delta \mathrm{PC}$} & \multicolumn{2}{|c|}{ Stand age } & \multicolumn{2}{|c|}{ Windthrow } & \multicolumn{2}{|c|}{ Park } & \multicolumn{2}{|c|}{$\Delta \mathrm{Ht}$} & \multicolumn{2}{|c|}{ Dist. } & \multicolumn{2}{|c|}{$\Delta \mathrm{Ht}$ :Dist. } \\
\hline & $\beta$ & SE & $\beta$ & SE & $\beta$ & $\mathrm{SE}$ & $\beta$ & SE & $\beta$ & $\mathrm{SE}$ & $\beta$ & SE & $\beta$ & $\mathrm{SE}$ & $\beta$ & $\mathrm{SE}$ & $\beta$ & SE \\
\hline 1 & 0.25 & 0.54 & & & & & & & & & & & & & & & & \\
\hline 2 & 1.31 & 0.55 & 5.91 & 1.60 & & & & & & & & & & & & & & \\
\hline 3 & 2.17 & 0.66 & 4.73 & 1.63 & & & -2.09 & 0.96 & & & & & & & & & & \\
\hline 4 & 1.31 & 0.57 & 5.36 & 1.69 & 0.01 & 0.02 & & & & & & & & & & & & \\
\hline 5 & 4.38 & 1.00 & 3.00 & 2.56 & & & & & & & & & -0.50 & 0.20 & -5.13 & 1.30 & 0.55 & 0.24 \\
\hline 6 & 1.19 & 0.76 & 5.75 & 1.77 & & & & & & & 0.24 & 1.10 & & & & & & \\
\hline 7 & 1.92 & 0.62 & 6.70 & 1.59 & & & & & -2.36 & 1.18 & & & & & & & & \\
\hline
\end{tabular}

$\dagger$ Note that negative parameter values imply a positive relationship due to negative covariate values representing decrease in stand area 
Table A2.6 Parameter estimates for models examining variation in stand-level trends (between circa 1994 and 2014) in abundance Mourning Warbler in aspen dominated mixedwood forests in central Saskatchewan. 85\% Confidence Intervals can be obtained as $\beta \pm 1.44 *$ SE. NOTE:

Parameter values were rescaled by multiplying with a constant (100) for ease of presentation, divide by 100 to obtain estimates.

\begin{tabular}{|c|c|c|c|c|c|c|c|c|c|c|c|c|c|c|c|c|c|c|}
\hline \multirow[b]{2}{*}{ Model } & \multicolumn{2}{|c|}{ Intercept } & \multicolumn{2}{|c|}{$\mathrm{PD}^{\dagger}$} & \multicolumn{2}{|c|}{$\triangle \mathrm{PC}$} & \multicolumn{2}{|c|}{ Stand age } & \multicolumn{2}{|c|}{ Windthrow } & \multicolumn{2}{|c|}{ Park } & \multicolumn{2}{|c|}{$\overline{\mathrm{c}} \mathrm{\textrm {Ht }}$} & \multicolumn{2}{|c|}{ Dist. } & \multicolumn{2}{|c|}{$\Delta \mathrm{Ht}:$ Dist. } \\
\hline & $\beta$ & $\mathrm{SE}$ & $\beta$ & $\mathrm{SE}$ & $\beta$ & $\mathrm{SE}$ & $\beta$ & $\mathrm{SE}$ & $\beta$ & $\mathrm{SE}$ & $\beta$ & $\mathrm{SE}$ & $\beta$ & $\mathrm{SE}$ & $\beta$ & SE & $\beta$ & SE \\
\hline 1 & 0.11 & 0.31 & & & & & & & & & & & & & & & & \\
\hline 2 & -0.21 & 0.35 & -1.80 & 1.03 & & & & & & & & & & & & & & \\
\hline 3 & -0.75 & 0.43 & -1.04 & 1.05 & & & 1.33 & 0.62 & & & & & & & & & & \\
\hline 4 & -0.07 & 0.38 & -1.26 & 1.12 & -0.02 & 0.02 & & & & & & & & & & & & \\
\hline 5 & -1.47 & 0.67 & -0.75 & 1.71 & & & & & & & & & 0.11 & 0.14 & 2.42 & 0.87 & -0.08 & 0.16 \\
\hline 6 & -0.52 & 0.49 & -2.23 & 1.13 & & & & & & & 0.65 & 0.70 & & & & & & \\
\hline 7 & -0.63 & 0.39 & -2.33 & 1.02 & & & & & 1.62 & 0.75 & & & & & & & & \\
\hline
\end{tabular}

$\dagger$ Note that negative parameter values imply a positive relationship due to negative covariate values representing decrease in stand area

Table A2.7 Parameter estimates for models examining variation in stand-level trends (between circa 1994 and 2014) in abundance Magnolia Warbler in aspen dominated mixedwood forests in central Saskatchewan. 85\% Confidence Intervals can be obtained as $\beta \pm 1.44 *$ SE. NOTE: Parameter values were rescaled by multiplying with a constant (100) for ease of presentation, divide by 100 to obtain estimates.

\begin{tabular}{|c|c|c|c|c|c|c|c|c|c|c|c|c|c|c|c|}
\hline \multirow[b]{2}{*}{ Model } & \multicolumn{3}{|c|}{ Intercept } & \multirow{2}{*}{$\begin{array}{l}\Delta \mathrm{PC} \\
\mathrm{SE}\end{array}$} & \multicolumn{2}{|c|}{ Stand age } & \multicolumn{2}{|c|}{ "Windthrow } & Park & \multicolumn{3}{|c|}{$\Delta \mathrm{HHt}$} & \multirow{2}{*}{$\begin{array}{c}\text { Dist. } \\
\text { SE }\end{array}$} & \multicolumn{2}{|c|}{$\Delta \mathrm{Ht}$ :Dist. } \\
\hline & $\beta$ & SE & $\beta$ & & $\beta$ & SE & $\beta$ & $\mathrm{SE}$ & $\beta \quad \mathrm{SE}$ & $\beta$ & SE & $\beta$ & & $\beta$ & SE \\
\hline 1 & 0.49 & 0.31 & & & & & & & & & & & & & \\
\hline 2 & 0.52 & 0.31 & -0.03 & 0.01 & & & & & & & & & & & \\
\hline 3 & -1.66 & 0.64 & & & & & & & & 0.30 & 0.13 & 3.08 & 0.74 & -0.22 & 0.14 \\
\hline 4 & 0.40 & 0.39 & & & & & 0.23 & 0.66 & & & & & & & \\
\hline 5 & -0.24 & 0.42 & & & 1.41 & 0.59 & & & & & & & & & \\
\hline 6 & 0.17 & 0.34 & & & & & 1.56 & 0.75 & & & & & & & \\
\hline 7 & 0.21 & 0.33 & -0.03 & 0.01 & & & 1.48 & 0.73 & & & & & & & \\
\hline 8 & 0.00 & 0.46 & -0.02 & 0.02 & & & 0.98 & 0.66 & & & & & & & \\
\hline
\end{tabular}


Table A2.8 Parameter estimates for models examining variation in stand-level trends (between circa 1994 and 2014) in abundance Yellowrumped Warbler in aspen dominated mixedwood forests in central Saskatchewan. 85\% Confidence Intervals can be obtained as $\beta \pm 1.44 *$ SE. NOTE: Parameter values were rescaled by multiplying with a constant (100) for ease of presentation, divide by 100 to obtain estimates.

\begin{tabular}{|c|c|c|c|c|c|c|c|c|c|c|c|c|c|c|c|c|c|c|}
\hline \multirow[b]{2}{*}{ Model } & \multicolumn{2}{|c|}{ Intercept } & \multicolumn{2}{|c|}{$\mathrm{PD}^{\dagger}$} & \multicolumn{2}{|c|}{$\Delta \mathrm{PC}$} & \multicolumn{2}{|c|}{ Stand age } & \multicolumn{2}{|c|}{ Windthrow } & \multicolumn{2}{|c|}{ Park } & \multicolumn{2}{|c|}{$\Delta \mathrm{Ht}$} & \multicolumn{2}{|c|}{ Dist. } & \multicolumn{2}{|c|}{$\Delta \mathrm{Ht}$ (Dist. } \\
\hline & $\beta$ & $\mathrm{SE}$ & $\beta$ & $\mathrm{SE}$ & $\beta$ & SE & $\beta$ & $\mathrm{SE}$ & $\beta$ & $\mathrm{SE}$ & $\beta$ & $\mathrm{SE}$ & $\beta$ & $\mathrm{SE}$ & $\beta$ & $\mathrm{SE}$ & $\beta$ & $\mathrm{SE}$ \\
\hline 1 & -0.06 & 0.06 & & & & & & & & & & & & & & & & \\
\hline 2 & 0.03 & 0.06 & 0.49 & 0.18 & & & & & & & & & & & & & & \\
\hline 3 & 0.04 & 0.08 & 0.47 & 0.19 & & & -0.03 & 0.11 & & & & & & & & & & \\
\hline 4 & 0.00 & 0.06 & 0.36 & 0.19 & 0.00 & 0.00 & & & & & & & & & & & & \\
\hline 5 & 0.03 & 0.13 & 0.21 & 0.33 & & & & & & & & & 0.01 & 0.03 & -0.12 & 0.17 & 0.01 & 0.03 \\
\hline 6 & 0.02 & 0.08 & 0.48 & 0.20 & & & & & & & 0.01 & 0.12 & & & & & & \\
\hline 7 & -0.01 & 0.07 & 0.43 & 0.18 & & & & & 0.16 & 0.13 & & & & & & & & \\
\hline
\end{tabular}

$\uparrow$ Note that negative parameter values imply a positive relationship due to negative covariate values representing decrease in stand area

Table A2.9 Parameter estimates for models examining variation in stand-level trends (between circa 1994 and 2014) in abundance Chipping Sparrow in aspen dominated mixedwood forests in central Saskatchewan. 85\% Confidence Intervals can be obtained as $\beta \pm 1.44 *$ SE. NOTE: Parameter values were rescaled by multiplying with a constant (100) for ease of presentation, divide by 100 to obtain estimates.

\begin{tabular}{|c|c|c|c|c|c|c|c|c|c|c|c|c|c|c|c|c|c|c|}
\hline \multirow[b]{2}{*}{ Model } & \multicolumn{2}{|c|}{ Intercept } & \multicolumn{2}{|c|}{$\mathrm{PD}^{\dagger}$} & \multicolumn{2}{|c|}{$\triangle \mathrm{PC}$} & \multicolumn{2}{|c|}{ Stand age } & \multicolumn{2}{|c|}{ Windthrow } & \multicolumn{2}{|c|}{ Park } & \multicolumn{2}{|c|}{$\Delta \mathrm{Ht}$} & \multicolumn{2}{|c|}{ Dist. } & \multicolumn{2}{|c|}{$\Delta \mathrm{Ht}$ (Dist. } \\
\hline & $\beta$ & $\mathrm{SE}$ & $\beta$ & $\mathrm{SE}$ & $\beta$ & SE & $\beta$ & SE & $\beta$ & $\mathrm{SE}$ & $\beta$ & SE & $\beta$ & SE & $\beta$ & SE & $\beta$ & SE \\
\hline 1 & 0.07 & 0.13 & & & & & & & & & & & & & & & & \\
\hline 2 & 0.31 & 0.14 & 1.35 & 0.40 & & & & & & & & & & & & & & \\
\hline 3 & 0.16 & 0.17 & 1.56 & 0.42 & & & 0.36 & 0.25 & & & & & & & & & & \\
\hline 4 & 0.25 & 0.15 & 1.13 & 0.43 & 0.01 & 0.01 & & & & & & & & & & & & \\
\hline 5 & -0.09 & 0.28 & 0.60 & 0.72 & & & & & & & & & 0.08 & 0.06 & 0.26 & 0.37 & -0.02 & 0.07 \\
\hline 6 & 0.40 & 0.19 & 1.49 & 0.44 & & & & & & & -0.20 & 0.27 & & & & & & \\
\hline 7 & 0.27 & 0.16 & 1.30 & 0.42 & & & & & 0.15 & 0.31 & & & & & & & & \\
\hline
\end{tabular}

$\uparrow$ Note that negative parameter values imply a positive relationship due to negative covariate values representing decrease in stand area 
Table A2.10 Parameter estimates for models examining variation in stand-level trends (between circa 1994 and 2014) in abundance Whitethroated Sparrow in aspen dominated mixedwood forests in central Saskatchewan. 85\% Confidence Intervals can be obtained as $\beta \pm 1.44 *$ SE. NOTE: Parameter values were rescaled by multiplying with a constant (100) for ease of presentation, divide by 100 to obtain estimates.

\begin{tabular}{|c|c|c|c|c|c|c|c|c|c|c|c|c|c|c|c|c|}
\hline \multirow[b]{2}{*}{ Model } & \multicolumn{2}{|c|}{ Intercept } & \multicolumn{2}{|c|}{$\Delta \mathrm{PC}$} & \multicolumn{2}{|c|}{ Stand age } & \multicolumn{2}{|c|}{ Windthrow } & \multicolumn{2}{|c|}{ Park } & \multicolumn{2}{|c|}{$\Delta \mathrm{Ht}$} & \multicolumn{2}{|c|}{ Dist. } & \multicolumn{2}{|c|}{$\bar{\Delta} \Delta \mathrm{Ht}:$ Dist. } \\
\hline & $\beta$ & SE & $\beta$ & SE & $\beta$ & $\mathrm{SE}$ & $\beta$ & SE & $\beta$ & SE & $\beta$ & SE & $\beta$ & $\mathrm{SE}$ & $\beta$ & $\mathrm{SE}$ \\
\hline 1 & 0.09 & 0.46 & & & & & & & & & & & & & & \\
\hline 2 & 0.17 & 0.42 & -0.06 & 0.02 & & & & & & & & & & & & \\
\hline 3 & -2.90 & 0.91 & & & & & & & & & 0.29 & 0.18 & 4.74 & 1.05 & -0.31 & 0.20 \\
\hline 4 & 0.16 & 0.58 & & & & & & & -0.18 & 0.98 & & & & & & \\
\hline 5 & -1.66 & 0.55 & & & 3.42 & 0.77 & & & & & & & & & & \\
\hline 6 & -0.21 & 0.51 & & & & & 1.53 & 1.14 & & & & & & & & \\
\hline 7 & -0.11 & 0.47 & -0.06 & 0.02 & & & 1.32 & 1.02 & & & & & & & & \\
\hline 8 & -1.21 & 0.58 & -0.04 & 0.02 & 2.59 & 0.82 & & & & & & & & & & \\
\hline
\end{tabular}

